\title{
Estrategias e imágenes sobre la crisis en el espacio social de la «nueva pobreza». Representaciones sociales $\mathbf{y}$ atribuciones causales
}

\author{
Ángel ZURDO ALAGUERO \\ Facultad de Ciencias de la Información \\ Departamento de Sociología VI \\ Universidad Complutense de Madrid \\ angel.zurdo@ccinf.ucm.es \\ Myriam LÓPEZ DE LA NIETA BEÑO \\ Colegio Universitario Cardenal Cisneros \\ myriamlopez@cu-cisneros.es
}

Recibido: 19-03-2013

Aceptado: 07-05-2013

\section{RESUMEN}

El artículo parte de una investigación cualitativa llevada a cabo en la Comunidad de Madrid que tomó como objeto de estudio el espacio social — enormemente heterogéneo - vinculado a la que tentativa y problemáticamente podríamos denominar 'nueva pobreza'. Es éste un espacio en proceso de ampliación desbocada, lo que apunta la emergencia de una nueva 'cuestión social'. A partir de este material empírico, el artículo analiza la diversidad de posiciones discursivas y las representaciones sociales sobre la crisis (y por extensión acerca de la situación de pobreza y privación), considerando también las estrategias que se articulan desde este espacio social para enfrentarla. Estas dimensiones se conformarían a partir de la confluencia compleja y dinámica de espacios ideológicos, contextos sociales, y actitudes vitales prototípicas. Por último, se atiende y analiza la atribución de responsabilidades que este colectivo de 'nuevos pobres' realiza sobre la crisis, con respecto a distintas instituciones políticas, económicas, y actores sociales.

Palabras clave: Crisis, nueva pobreza, privación, representaciones sociales, discursos sociales

\section{Strategies and images with regard to the crisis in the social space of «new poverty». Social representations and causal attributions}

\begin{abstract}
This article is based on qualitative research that was carried out in the region of Madrid, which took as objective the exploration of the social space - enormously diverse - linked to that which we might tentatively and problematically call 'new poverty'. This space is in the process of unbridled amplification, suggesting the emergence of a new 'social question'. Based on empirical evidence, this paper analyzes the diversity of discursive positions and social representations with regard to the crisis (and in extension about poverty and deprivation), also considering the strategies articulated to confront it. These dimensions would be conformed from the complex and dynamic confluence of ideological spaces, social contexts, and prototypical vital attitudes. Finally, the paper addresses and discusses the attribution of responsibilities that this
\end{abstract}


collective of 'new poor' takes upon themselves because of the crisis with respect to distinct political and economic institutions, and social actors.

Keywords: Crisis, 'new poverty', privation, social representations, social discourses

\section{REFERENCIA NORMALIZADA}

Zurdo Alaguero, Á. y López de la Nieta Beño, M. (2013). Estrategias e imágenes sobre la crisis en el espacio social de la «nueva pobreza». Representaciones sociales y atribuciones causales. Cuadernos de Relaciones Laborales Vol. 31, núm. 2, p. 383-433.

SUMARIO: Introducción. 1. La 'crisis' como concepto analítico y como fenómeno social. 1.1. El concepto de crisis. 1.2. La crisis actual. Una breve caracterización. 2. La percepción social de la crisis: Las causas y los responsables. 2.1. La universalización de la culpa: la responsabilización individual. 2.1.1 Los excesos de la cultura consumista y las conductas consumistas irracionales. 2.1.2. Los déficits y los errores estratégicos del sujeto individualmente considerado. 2.2. La clase política y los partidos políticos: entre la corrupción y la incompetencia. 2.3. Las disfunciones de la economía capitalista. 2.4. El 'chivo expiatorio': los inmigrantes y el acaparamiento de recursos limitados. 3. Estrategias y propuestas para salir y/o amortiguar el impacto de la crisis. 3.1. Las estrategias individuales. 3.1.1 El planteamiento meritocrático individual. 3.1.2. La búsqueda activa de recursos. 3.1.3. La optimización de los recursos disponibles y las adaptabilidad desdencente en los patrones de consume. 3.1.4. Las estrategias extremas de supervivencia multimovilizada: los espacios del "trapicheo". 3.1.5. Las huidas y los imaginarios escapistas. 3.2. Las estrategias colectivas. 3.2.1. El refugio grupalista: El comunitarismo regresivo. 3.2.2. La movilización colectiva. 4. A modo de conclusión. 5. Bibliografía.

\section{Introducción}

En las páginas que siguen, pretendemos realizar una aproximación tentativa a las posiciones discursivas y las estrategias de 'gestión' de la crisis, que elaboran aquellos sectores de las clases populares y medias que más se han visto afectados por el proceso de empobrecimiento social asociado a la crisis económica de los últimos años, y que aglutinamos en la categoría de 'nueva pobreza' ${ }^{1}$. El contexto del análisis de nuestro material empírico no se circunscribe a los aspectos económicos de la crisis. La conceptualización de la crisis en los discursos sociales es compleja, aunque se construya a partir de la esfera de lo económico, interrelaciona múltiples dimensiones de lo social, y de esa forma, tiende a contraponerse a los discursos técnicos, y a gran parte de los discursos académicos (que 'contaminan' el debate político), que aíslan artificialmente la esfera económica del resto de ámbitos de lo social, y que de esta manera, ofrecen una versión mutilada de la crisis.

1 Como se ha señalado en el artículo -incluido en este mismo volumen-, utilizamos el concepto de «nuevos pobres» o «nueva pobreza» para referirnos a los sujetos y grupos desestabilizados por los actuales acontecimientos, derivados de las manifestaciones del capitalismo contemporáneo y sus crisis económicas (especialmente la actual), y que puede implicar — O no- la acción acumulada de otros factores exclusógenos. 
El contenido de este trabajo se deriva de una investigación cualitativa desarrollada en la Comunidad de Madrid ${ }^{2}$, en dos fases diferentes. Una primera fase del trabajo de campo se llevó a término a lo largo de la primavera y principios del verano de 2011 (se organizaron seis grupos de discusión), y una segunda fase se desarrolló a lo largo de los meses de verano y otoño de 2012 (realizándose ocho entrevistas abiertas y dos grupos triangulares) ${ }^{3}$. La segunda fase del campo se concibió y diseñó como complemento de la primera, con el fin de acceder a aquellos perfiles más específicos (a través de las entrevistas abiertas), y a variantes discursivas menos centrales socialmente (tratando al mismo tiempo de fijar los vectores de desarrollo y 'escape' de los discursos circulantes), con ese fin, se utilizó la práctica de investigación del grupo triangular. En ese sentido, el material nos permite acceder, desde una perspectiva temporal, a variaciones sutiles, pero al mismo tiempo significativas, de la argumentación y el 'foco' de atención en los discursos (con respecto a la atribución de responsabilidades, a las estrategias ante la crisis, a la valoración los movimientos sociales, etcétera). Dado que la crisis, lejos de configurarse como un fenómeno puntual, se concreta como un proceso social de largo recorrido, disponer de material empírico producido en dos momentos distintos, lejos de implicar una debilidad, se convierte en un activo importante.

La multidimensionalidad de los discursos sociales sobre la crisis, a la que hemos hecho referencia, pone a prueba la consistencia y coherencia interna de las distintas posiciones discursivas (variantes que además tienden a multiplicarse en el contexto de la elevada heterogeneidad social —en términos de habitus de clase, trayectorias

2 Proyecto subvencionado por la Comunidad de Madrid y la Universidad Complutense de Madrid (convocatoria de diciembre de 2010) con número de referencia CCG10UC/HUM-4984, y que llevó por título "Miradas sobre la pobreza: representaciones sociales del sector de nuevos pobres de la Comunidad de Madrid en un contexto de crisis económica".

${ }^{3}$ Incorporamos aquí una reseña telegráfica del diseño del trabajo de campo, que se llevó a cabo en la Comunidad de Madrid. Una versión más matizada puede encontrarse en el artículo "Marcos interpretativos de lo social en la vivencia de la «nueva pobreza»", en este mismo volumen. Todos los participantes se encontraban en situación de pobreza. Grupos de discusión: (GD1) Jóvenes en paro de clase media baja y baja con estudios medios; (GD2) Varones adultos de clase obrera, parados de larga duración; (GD3) Adultos de clase media baja en paro; (GD4) Inmigrantes rumanos adultos en paro; (GD5) Mujeres responsables de familias monoparentales en paro; (GD6) Jóvenes de clase obrera en paro. Grupos triangulares: (GT1) Jóvenes 'maduros' movilizados y en paro; (GT2) Adultos de clase media funcional en paro. Entrevistas: (E1) Mujer trabajadora pobre (44 años), con cargas familiares; (E2) Varón inmigrante marroquí (36 años), con cargas familiares, recoge cartón y plástico; (E3) Mujer inmigrante latina en paro (33 años), ha trabajado en servicio doméstico; (E4) Varón (53 años) de clase obrera alta en paro, prestaciones agotadas; (E5) Varón (58 años) de clase media (autónomo) en paro y sin prestaciones, desahuciado; (E6) Trabajador pobre de clase obrera (30 años); (E7) Mujer trabajadora pobre (28 años) con trabajo temporal; (E8) Varón, adulto joven (32 años) ingeniero superior, trayectoria laboral precaria y discontinua, en paro. 
vitales, niveles de privación...- del colectivo de nuevos pobres). Los discursos están atravesados por múltiples puntos de tensión, derivas y fracturas. Podría argüirse que ese escenario es una constante en cualquier investigación cualitativa (correlato de la propia complejidad social, y de la multiplicidad estructural de posiciones sociales), pero constatamos que la 'inconsistencia discursiva' es especialmente notable en los discursos sobre la crisis. Esa mayor endeblez y fragilidad es absolutamente lógica, ya que los sujetos se ubican en un campo social especialmente inestable (en el marco de una crisis 'en marcha'), atravesado por una elevadísima incertidumbre. En ese contexto, los distintos colectivos tratan de elaborar y ensayar - dificultosamente- explicaciones, modelos de comprensión, representaciones sociales de la crisis, dando forma a diagnósticos complejos, y a la vez 'difusos' (e incluso deficientemente integrados), que tratan de articular diferentes perspectivas al incorporar, en distintas configuraciones, su experiencia inmediata 'micro', y el contexto 'macro': el nivel de 'lo político', 'lo económico', etcétera ${ }^{4}$. Así pues, los 'nuevos pobres' perciben con claridad la complejidad de la crisis, y la abordan - desde una perspectiva explicativa - partiendo de su propia ubicación en el campo social.

\section{La 'crisis' como concepto analítico y como fenómeno social}

Antes de abordar el análisis de nuestro material empírico, realizaremos una breve aproximación al propio concepto de crisis, un concepto de uso generalizado - y problemático - en el campo de la sociología, y también incorporaremos algunas aproximaciones de carácter teórico a la actual crisis que ofrecen líneas interpretativas que incorporan las dimensiones social, política e ideológica.

Partimos de una conceptualización 'social' amplia de la crisis, lo que implica necesariamente su consideración como fenómeno complejo, que repercute sobre múltiples esferas de lo social conectadas dinámicamente entre sí. Creemos que la crisis actual debe conceptualizarse prioritariamente como una "crisis de lo social" (Velasco, 2012: 205). Cabe apuntar al respecto que fue Marx "quien desarrolla en las ciencias sociales, por vez primera, un concepto de crisis sistémica" (Habermas, 1995: 15) . La frecuente reducción analítica de la 'realidad' de la crisis a su dimen-

\footnotetext{
${ }^{4}$ Podemos apuntar con Žižek que "Cuando el acontecer normal de las cosas se ve traumáticamente interrumpido, queda abierto el campo para una competición ideológica «discursiva»" (Žižek, 2011: 23), una competición sobre qué narrativa explica mejor las cosas (ibid.). Ese es el contexto de la inconsistencia discursiva que muestra nuestro material empírico.

${ }_{5}^{5}$ Pese a ello, algunos autores señalan que en la obra de Marx no encontramos una verdadera 'teoría de la crisis' dado que el autor alemán no se concentra en el análisis y caracterización sistemática de la crisis como "fenómeno catastrófico", sino que 'simplemente' tiende
} 
sión económica (normalmente limitada a indicadores macroeconómicos típicos), supone perder por el camino sus implicaciones institucionales e ideológicas. Comporta también obviar los procesos de ejercicio de poder y las dinámicas sociales asociadas a la situación de crisis, y sobre todo, termina sepultando las relaciones y experiencias sociales de aquellos sujetos - tanto a nivel individual como grupalque conviven con, sobreviven y sufren la crisis. Finalmente, esta conceptualización económica (legítima, pero extremadamente estrecha) termina obviando los procesos de cambio y reestructuración social a los que estamos asistiendo. En cierta medida, la caracterización unidimensional de la crisis consigue - a través de un potente proceso de objetivación - desplazar a un segundo plano en la agenda política (y de una forma no inocua ideológicamente), la dimensión social y los dramáticos efectos sociales de la crisis.

\subsection{El concepto de crisis}

El término griego krisis significa decisión, hace referencia a un momento decisivo. Como es señalado por diversos autores, el uso originario del concepto, nos remite al ámbito de la medicina, donde la crisis definiría "el punto de inflexión en el que una enfermedad se decide o se resuelve, bien hacia el polo de la curación, o bien hacia la muerte del organismo" (Ríos, 2012: 18). Es importante tomar conciencia - como indica Carrasco-Conde (2012: 135) — de que "lo que se entiende hoy por crisis se aleja de su pasado etimológico griego" que liga el concepto a un momento decisivo. Para Morin (1995: 160) el concepto de crisis, en su sentido moderno - en el ámbito de lo social—, se desliza y vincula fundamentalmente a la incertidumbre. La crisis aporta fundamentalmente indeterminación, "debilita la posibilidad de previsión" (ibíd.), y por lo tanto, implicaría una regresión del determinismo del sistema, y una progresión de la inestabilidad, del riesgo social, de los desórdenes (ibíd. 164). La centralidad de la incertidumbre en el contexto de la crisis, es algo que se refleja con meridiana claridad en nuestro trabajo de campo. Como veremos, los 'nuevos pobres' están sumidos en la perplejidad y la incertidumbre (en muchos casos, con una fuerte deriva anómica). Pero, para Morin, la situación de incertidumbre social no es necesariamente perniciosa, ya que genera la posibilidad de acción, de decisión, de cambio, de transformación. Por eso, el autor francés concluye: "la crisis es un momento indeciso y decisivo a la vez" (ibid.: 160).

La definición y uso académico del concepto de crisis en el ámbito de la economía resulta mucho más nítido que en el campo sociológico, lo que contribuye a la difusión social de la conceptualización económica de la crisis. En la disciplina económica el concepto 'crisis' se operacionaliza de manera más transparente en función de ciertos indicadores macroeconómicos ligados fundamentalmente al crecimiento económico (por lo tanto, domina una conceptualización estrecha de la

a subrayar "la inherente propensión a la crisis que subyace a la permanente inestabilidad de la vida social en el contexto del capitalismo" (Clarke, 1994: 190). 
crisis, que deja buena parte de lo económico fuera). Quizá por ello - unido a la proyección hegemónica en la esfera política y mediática de la conceptualización económica-, en los discursos sociales cotidianos las referencia a la crisis, se circunscriben a la crisis económica.

Usualmente vinculamos el concepto (no sólo en el ámbito cotidiano sino también en el académico) a que "la cosa no va bien", o que "todo va mal" (Morin, 1995: 159). Pero, en el ámbito de la sociología, el concepto crisis frecuentemente funciona en una lógica 'sustitutiva' de otros conceptos, en ocasiones mucho más precisos. Así, el término crisis puede funcionar — dependiendo de las tradiciones teóricas en las que se incardine su uso - como sinónimo o sustitutivo de: disfunción, desestructuración, desorganización, desorden, inestabilidad, desregulación, ruptura, declive, sobrecarga, aparición o agudización de un conflicto, proceso de cambio o expectativa de inminente transformación (frecuentemente ligado al conflicto), perturbación, involución, inestabilidad, situación de tensión social, déficit o carencia, pérdida, y un largo etcétera.

Desde esa apertura semántica, el concepto puede ser aplicado sin apenas problemas a cualquier ámbito, institución o proceso social (involucrando, por ejemplo, a la familia, el mercado de trabajo, la religión, el sistema educativo, la identidad de género, 'lo rural', y un largo etcétera). En ese sentido, podríamos hablar con total propiedad, de una situación caracterizada por un uso abusivo y confuso del concepto crisis, e incluso, trascendiendo el ámbito académico, hacer mención a "su colonización de la experiencia contemporánea" (ibid.) - especialmente en un contexto como el actual en el que la crisis económica se erige en el elemento mediático central- Pero paralelamente, como correlato de esta difusión social y semántica, se produciría un proceso de 'vaciamiento' del propio concepto de crisis (Cadahia 2012: 171).

Desde una perspectiva sociológica, resulta mucho más útil limitar el uso del concepto crisis a un nivel macrosocial, para hacer referencia a una situación de inestabilidad estructural generalizada que surge como resultado de contradicciones internas. Referirnos a una situación de inestabilidad estructural, implica aceptar que la crisis se define siempre con respecto a periodos de estabilidad relativa (Morin, 1995: 171). Para completar la concreción macro del concepto crisis podemos recurrir a Wallerstein (1984: 11) para el que "el término crisis no debería ser degradado hasta convertirlo en un mero sinónimo de cambio cíclico. Debería reservarse para aquellas épocas de tensión dramática que son algo más que una coyuntura y marcan un hito en las estructuras de longue durée". Para Wallerstein, las verdaderas crisis poseen un elemento de excepcionalidad histórica, y se vinculan a marcados procesos de reestructuración que el autor concreta en la esfera económica, si bien reconoce sus profundas implicaciones sociales: "las crisis describirían, pues, esos raros momentos históricos en que los mecanismos de compensación habituales dentro de un sistema social resultan tan ineficaces desde el punto de vista de tantos y tan importantes actores sociales que empieza a producirse una importante reestructuración de la economía (y no una mera redistribución de las ventajas dentro del sistema), la cual es considerada retrospectivamente como inevitable" (ibid.). 
Por su parte, Morin (1995) ilustra — en la estela de las aportaciones de Marx y Freud - cómo la crisis puede tener un valor revelador y un valor realizador. La crisis poseería un valor revelador (de lo latente, de lo inconsciente), estrechamente ligado al conflicto, a la contradicción. Así, "La crisis [...], revela, de repente, la presencia, la fuerza y la forma de aquello que, en tiempos normales o en situaciones normales, permanece invisible" (ibid.: 159). En ese sentido, la crisis aparecería como un momento de la verdad, de gran valor para el conocimiento de lo social. El valor realizador de la crisis, por su parte, aparece en tanto en cuanto la evolución social "se concibe no como un proceso lineal, sino como un fenómeno marcado por discontinuidades y rupturas" (ibid.) ligadas frecuentemente a situaciones de crisis. "La crisis pone en movimiento fuerzas de transformación" (ibíd.: 160), que pueden eventualmente poner en marcha, aunque sea fugazmente, aquellos elementos que favorecen el cambio y la evolución. No obstante, la crisis no tiene porqué resultar necesariamente evolutiva, y como indica el propio Morin (ibid.: 171) puede "reabsorberse en una vuelta al statu quo" (lo que implicaría la reasimilación de la perturbación) o, incluso, en el extremo, vincularse a la desintegración del sistema.

Desde una perspectiva temporal, la crisis está especialmente ligada al presente en la conciencia de los actores, de esa manera, las crisis "se viven en presente" (Gómez, 2012: 101). Además, en su origen, el concepto de crisis se asociaba a lo efímero, a lo urgente, a lo excepcional, a una situación transitoria (Sánchez, 2012: 54), señalando "un punto, casi una cúspide" (Lanceros, 2012: 84). Sin embargo, en su sentido contemporáneo, esa caracterización de la crisis como evento efímero y fugaz pierde su razón de ser, en el contexto de una modernidad a la que se identifica como 'instalada' en la crisis ${ }^{6}$. De hecho, la actual crisis se empeña machaconamente en evidenciar su dimensión 'procesual' — y de esa manera, su proyección futuraLa dimensión procesual está clara, pero asumiéndola, cabe plantearse si la 'cronificación' de la crisis hace necesaria una conceptualización alternativa. En esa dirección, Sánchez (ibíd:: 54) se pregunta cuánto debe durar una crisis para que sea pertinente seguir hablando en términos de crisis, ya que su prolongación en el tiempo parece transformarla en un 'estado' de la sociedad, más que identificar un periodo crítico asociado a una situación de fuerte tensión en las estructuras sociales.

En las mismas coordenadas se ubica Carrasco-Conde (2012: 125), que observa - en el contexto actual - que la crisis "consiste en un mecanismo de reestructuración que tiene lugar dentro de un proceso de largo recorrido" (ibid.: 136). Pero recogiendo las aportaciones de Gumbrecht, termina disolviendo parcialmente la dimensión procesual al referirse a "una forma de «lento presente»: un presente estancado", un "paréntesis" (ibíd.). El problema es que resulta difícil hacer "concordar' sin fricciones nociones como 'proceso' y 'estancamiento'. Sí nos parece más interesante la apreciación de la autora sobre la "normalidad de la crisis" —en el

${ }^{6}$ Para Koselleck (2007) la noción de 'crisis' es la descripción que la modernidad hace de sí misma, es su forma de experimentarse. 
contexto de su dilatación temporal - que nos remitiría a la normalización social de la crisis (Velasco, 2012: 208), que para nosotros mostraría una doble dimensión: la crisis se vincula a lo que es 'normal', lo corriente, lo habitual, lo cotidiano, pero también la crisis 'se hace norma'. En este segundo sentido, no hay que olvidar la frenética y lesiva - para las clases populares - actividad legislativa que 'normativiza la crisis', y que tiene un marcado carácter disciplinante (en ámbitos como el mercado de trabajo, la sanidad, la educación...). La noción 'normalización de la crisis', permite reflejar - y de manera precisa - la 'vivencia' subjetiva de la crisis que, en este caso, sí puede corresponderse con una experiencia de estancamiento vital (asociada, por ejemplo, a la imagen de estar en 'el pozo' que aparece en nuestro material empírico), pero, desde una perspectiva macro, no resulta apropiado vincular la crisis, por mucho que se prolongue, con la 'parálisis social', todo lo contrario. Por consiguiente, la crisis se configura como una realidad enormemente paradójica, especialmente desde un punto de vista temporal.

\subsection{La crisis actual. Una breve caracterización}

Desde nuestro punto de vista, la crisis actual se configura como una crisis social de carácter generalizado, como un verdadero fenómeno social total, puesto que en su realidad concreta atraviesa e interconecta múltiples esferas de lo social (incluyendo, claro está, la económica). La crisis toma la forma de una totalidad concreta 'traspasada' por contradicciones sociales, culturales, ideológicas y políticoeconómicas (Domínguez, 2000). El propio Domínguez, hace notar que el desarrollo histórico de las sociedades capitalistas tardías pone en duda el significado tradicional de las crisis económicas, que ya no pueden ser consideradas como un proceso 'autónomo'.

Si realizamos un recorrido rápido por los trabajos que se centran en el análisis de la crisis actual observaremos la fuerte preeminencia de las aportaciones estrictamente económicas. Son textos en los que el concepto crisis se usa de forma no 'calificada'. La referencia a la crisis en abstracto sólo puede referirse a la crisis económica. Las aportaciones sociológicas en torno al análisis de la crisis - mucho menos numerosas - , utilizan de una manera mucho más 'moderada' el concepto (y usualmente para referirse de manera restringida a la crisis económica), 'limitándose' a la identificación y análisis de los efectos sociales de la crisis económica (especialmente en términos de aumento cuantitativo de la desigualdad social y la pobreza). Estos trabajos no suelen identifican una situación de 'crisis social', formulación que como tal, está prácticamente ausente en la literatura. Parecería existir una cierta resistencia a establecer un marco de análisis y teorización multidimensional, sometiéndose de facto, a la propuesta interpretativa hegemónica que restringe la crisis a su dimensión económica. Es así relativamente excepcional la identificación de una situación convulsa que afecta a múltiples esferas de lo social, que tensiona y deforma la estructura social (en niveles muy diversos) y que afecta a la configuración del 
propio orden social. ${ }^{7}$ Limitando el nivel de análisis a lo económico, la crisis resulta mucho más inocua ideológica y políticamente.

No es sorprendente que encontremos una amplísima y reciente bibliografía de orientación económica sobre la crisis - aunque frecuentemente incorpore derivaciones sociológicas y hasta filosóficas-, pero son mucho más escasos los textos que tratan de abordar la crisis desde una perspectiva empírica plenamente sociológica. Sin ánimo de exhaustividad, algunas excepciones podemos encontrarlas en los trabajos contenidos en Tezanos (2012), también algunos de los capítulos del volumen coordinado por Guerra y Tezanos (2012), y otras aportaciones como las del Colectivo Ioé (2011 y 2012), Alonso et al. (2011), Salido (2012), Navarro (2012), López y Renes (2011), y Laparra y Pérez (2010 y 2012). En estas aportaciones tiende a dominar claramente una aproximación cuantitativa, y una especial preocupación por las consecuencias de la crisis en términos de desigualdad social, polarización social y depauperación. Resultan también interesantes desde una perspectiva sociológica aquellos trabajos que, abordando la crisis desde una perspectiva económica, se insertan en la tradición de la económica-política, como por ejemplo, los reunidos en el volumen coordinado por Gómez Serrano (2011), y algunos trabajos de orientación más divulgativa como los del Observatorio Metropolitano (2011) para el caso español - y de Stiglitz (2012), que incorporan un marco interpretativo más 'social'.

En ningún caso podemos —ni debemos—, analizar la crisis económica actual de forma aislada. La crisis se presenta como una realidad compleja y multidimensional, cuyo sentido está 'anclado' en el pasado (Augé, 2012: 69). De ahí que los esfuerzos de comprensión y explicación deban remontarse mucho más allá de la fecha del estallido de la crisis financiera, y requieran abrirse a una perspectiva social 'compleja', que incorpore la consideración de otras dimensiones de lo social. De manera acertada, escribe Morin (2011) que "el hecho de que [...el] carácter complejo de la crisis planetaria sea generalmente ignorado indica que la multicrisis también es cognitiva”. Y no sólo cognitiva, apuntaríamos por nuestra parte, sino eminentemente ideológica, lo que se expresa con claridad en el desplazamiento - cuando menos sorprendente, y en ningún caso azaroso- del foco de atención de los mercados (especialmente los financieros) hacia el Estado (concretamente hacia los niveles de gasto público y las políticas sociales sobre las que se concentra la actividad política que eufemística y cínicamente se define como de 'reforma'). Este deslizamiento paradójico ilustra claramente cómo "los centros del poder capitalista, liderados por un sector financiero que ha mantenido intacta su capacidad política, han presionado de forma exitosa para exigir su rescate por parte de los Estados y para relanzar

${ }^{7}$ Los textos que se articulan en torno al concepto de crisis y que analizan conjuntamente su dimensión política, económica, social... no son demasiado abundantes, como excepción, podemos considerar el texto de Camilleri (1976), a parte de las más recientes aportaciones de Morin $(1995,2011)$ que manejamos en este artículo. 
luego una alucinante y ambiciosa contraofensiva" contra el Estado Social (Observatorio Metropolitano, 2011: 11).

Morin (2011) diagnostica una situación de policrisis, que según el autor derivaría del proceso de globalización. Para Morin la globalización no sólo generaría su propia crisis, sino que su dinamismo acarrea crisis múltiples y variadas a escala planetaria, crisis que son eminentemente interdependientes entre sí, como son la crisis económica, la crisis ecológica, la crisis de las sociedades tradicionales, la crisis demográfica, la crisis urbana, la crisis del mundo rural, la crisis política, la crisis de las religiones (a pesar, matiza Morin, de su avance sobre la laicidad, también en crisis), la crisis del humanismo universalista, la crisis del desarrollo, etcétera. Así, es la civilización occidental (que ha generado en su dinámica la crisis de la globalización) la que finalmente está en crisis. Para el autor francés, la actual situación se caracteriza por una situación de extraordinaria incertidumbre con respecto al futuro, unida a un contexto presente de precariedad y angustia que "engendra reflujos hacia el pasado, es decir, hacia las raíces culturales, étnicas, religiosas y nacionales" (ibid.).

Desde posiciones más foucaultianas la crisis se interpreta en términos de dispositivo discursivo (Cadahia y Velasco 2012: 8), —lo que implica destacar su dimensión ideológica一, dispositivo atravesado por evidentes mecanismos de poder (ibid.: 9), y que resulta estrictamente funcional al mantenimiento del propio sistema de dominación. Así, para estos autores "La crisis se convierte en un mecanismo de normalización y ocultamiento de los cambios que precisa el actual poder para seguir expandiéndose" (ibíd.). En ese sentido, la actual crisis no se concreta en posibilidades de cambio 'progresivo', sino que se enroca, como ya señalaba Morin, en estrategias de cambio 'conservadoras' pilotadas 'desde arriba'. Es por ello que la intervención estatal, la actividad frenética de 'reformas', los cambios en marcha, están atravesados por la paradoja de una cierta 'parálisis' de fondo. El objetivo prioritario es, pues, la estabilización sistémica aunque sea a través de un proceso de incesante cambio.

Por su parte Koselleck, en un análisis que resulta perfectamente aplicable a la situación actual de crisis, observa la estrecha vinculación entre la identificación de la crisis y la legitimación de la acción política concreta: “...el diagnóstico de la crisis se convirtió en el título de legitimación de la acción política" (cfr. Sánchez, 2012: 52). La situación de 'excepción', el elemento 'crítico'/decisivo, e incluso la puesta en escena 'dramática' que rodea la identificación política de la crisis, tiene como corolario la reducción de facto de las posibles vías de reconducción o gestión política (también rodeadas de un discurso de excepcionalidad), y por tanto, tiende a legitimar las políticas concretas de intervención disciplinante (incluso de manera significativa entre quienes las sufren), en tanto en cuanto, no existiría ningún tipo de alternativa viable.

La construcción de la crisis como un "marco categorial incuestionable a la hora de pensar nuestro presente" (Cadahia y Velasco, 2012: 7), no solo contribuye a fijar la agenda política y social - a través del indispensable concurso de los medios-, sino que termina 'imponiendo' los términos en los que se puede, y debe, pensar la 
crisis. Eso hace que, a pesar de la indignación generalizada, y pese a la movilización ciudadana, las durísimas políticas dirigidas hacia la voladura controlada de los derechos sociales, hayan sido acompañadas de un creciente clima de resignación social. Como señala Berardi (2012: 11), aunque durante los últimos años se han multiplicado en el paisaje planetario bruscas rupturas, éstas no han concretado un cambio en el paradigma dominante, no han implicado un movimiento de autoorganización consciente (desde la base social), o una agitación revolucionaria. Básicamente, añadimos nosotros, porque no parece disponerse de -0 al menos no circulan socialmente con amplitud- otros conceptos, modelos, paradigmas... para pensar lo posible. También Slavoj Žižek, (2011: 23) confluye en su análisis: “...aunque las crisis sacuden la autocomplacencia de la gente, obligándola a cuestionar los fundamentos de sus propias vidas. [...] las premisas básicas de la ideología dominante, lejos de ser puestas en duda, se ven reafirmadas incluso más violentamente". Así, su análisis desemboca en un diagnóstico especialmente pesimista: los efectos inmediatos de la crisis no se concretarán en el auge de la política emancipatoria radical, sino que más bien, Žižek prevé el aumento del populismo racista, el incremento de la pobreza, nuevas guerras, el crecimiento de la desigualdad y la polarización social, etcétera.

El panorama político se ha caracterizado por la implementación de una estrategia, especialmente nítida y poderosa, de "normalización política de la crisis financiera" (Velasco, 2012: 207), estrategia compleja, pero realmente muy exitosa hasta el momento, que logra contener el malestar social con respecto a las elites económicas - y el sistema capitalista - en niveles no desestabilizantes (cuestión que se expresa con claridad meridiana en nuestro material empírico cualitativo). Como recuerda de nuevo Žižek (2011: 25) “...en la actual crisis, la tarea central de la ideología dominante es imponer una narrativa que echará la culpa del colapso no al sistema capitalista global como tal, sino a desviaciones secundarias y contingentes".

Además, la insistencia en la austeridad y el sacrificio que son señalados como inevitables (conceptos que rescatan y enfatizan discursivamente una dimensión y estrategia 'moralizante', ya que marcan una vía de ascetismo y penitencia que permitiría redimir los pecados y excesos pasados - de los que somos responsables todos-, y promete la salvación futura - la salida de la crisis-), hace que se pierda de vista la realidad social objetiva: la degradación de las condiciones materiales de existencia de los sujetos, la situación de privación cada vez más generalizada, el aumento de la pobreza, el incremento desbocado de la desigualdad y polarización social, etc. Tales procesos parecerían ser degradados a la condición de irrelevantes 'daños colaterales' (Bauman, 2011), sepultados por el objetivo del crecimiento y la estabilización macroeconómica.

Entre otros, Rocco (2012: 159) afirma que "la actual crisis económica implica una crisis del Estado", pero más que una relación de 'implicación', o incluso de simple 'contagio', se trata de un verdadero proceso de desplazamiento del foco de la crisis desde el ámbito de lo económico al espacio del Estado. Es incuestionable que la crisis introduce elementos de deslegitimación, que afectan especialmente al modelo de democracia representativa liberal, aunque los efectos más intensos se 
concretan en el modelo social. El declive 'cronificado' del estado social (asociado a una intensa reorganización tendente hacia la privatización de servicios y prestaciones, a un debilitamiento de su universalismo, y a una 'externalización' que también se apoyó de manera importante en el Tercer Sector), quedó oculto durante el periodo expansivo de crecimiento económico, bajo la marea del crédito, la expansión paralela del consumo privado (que generó una ola de optimismo, vinculado a la imagen social - exagerada - de un bienestar creciente y generalizado), y también bajo la idealización generalizada del modelo político asociado al proyecto de integración europea.

Las agresivas 'reformas' del modelo de bienestar, implican una estrategia de intensa socialización descendente de los costes de la crisis, basada en una distribución fuertemente regresiva y asimétrica que desplaza los mayores costes hacia las clases populares, que no podrán acudir al mercado para 'compensar' los recortes. Para Velasco (2012: 214) "Si durante el siglo XX la «invención de lo social» [...], fue la estrategia necesaria para optimizar el sistema de producción capitalista, hoy [...la crisis] es de lo social como dispositivo de normalización del capitalismo". Los servicios sociales, y concretamente las políticas de lucha contra la exclusión, son dos de los espacios (aunque no los únicos) donde se han dejado sentir con dureza las políticas de recortes. Ello tiene consecuencias directas para el colectivo de 'nuevos pobres', que encuentran una dificultad creciente para acceder a unas ayudas cada vez más exiguas, $\mathrm{y}$ sobre las que existe una creciente presión social.

Por otra parte, el marcado proceso de desregulación, la intensa desarticulación de políticas sociales, y por supuesto, la destrucción masiva de puestos de trabajo, con sus consecuencias demoledoras, no solo desde el punto de vista material, sino también en términos de identidad social, potencian los efectos anómicos de la crisis (Velasco 2012: 215), en su sentido mertoniano. Recordemos que Merton (reelaborando el concepto propuesto por Durkheim), define la situación anómica en términos de "quiebra de la estructura cultural, que tiene lugar en particular cuando hay una disyunción aguda entre las normas y los objetivos culturales y las capacidades socialmente estructuradas de los individuos del grupo para obrar de acuerdo con aquellos" (Merton, 1995: 241). Esta dislocación se acentúa drásticamente en el contexto de la crisis, afectando especialmente a las clases populares que se incorporaron durante la etapa de crecimiento a consumos normalizados, identificados socialmente como prototípicos de estilos de vida de 'clase media', y que en el actual proceso de contracción económica no sólo pierden capacidad adquisitiva (abandonando esas pautas de consumo, con las consecuencias identitarias que ello conlleva), sino también el trabajo, fuente primordial de esa identidad social ahora extremadamente deteriorada que empuja hacia una situación anómica.

Con respecto a los discursos sociales circulantes en torno a la crisis, es evidente que, en su configuración, están muy condicionados por la labor de los medios de 
comunicación $^{8}$. A pesar del evidente éxito (en términos de difusión social) de las metáforas sobre la crisis elaboradas en los discursos expertos de los economistas (vid. Lizcano, 2008 y 2012), no debemos caer en la tentación de adoptar una posición mecanicista; los discursos 'populares', si bien abrazan — y hasta amplificanalgunas de las metáforas más potentes difundidas a través de los medios de comunicación, tienen 'vida propia', son elaboraciones complejas que surgen a partir de la interacción concreta en contextos sociales específicos, pero al mismo tiempo, también complejos. Como nos recuerdan Orellana et al. (2007: 75), "los hablantes no se hacen eco de cualquier hallazgo metafórico producido en los medios; no toda metáfora pronunciada es reproducida y cobra aliento social". Es cierto que los grupos sociales reelaboran su discurso sobre la crisis retomando frecuentemente las imágenes, metáforas, clichés, y tópicos elaborados por las distintas elites que son posteriormente amplificados y filtrados selectivamente por los medios. Para nuestro colectivo de 'nuevos pobres' las noticias periodísticas aparecen como un referente discursivo central (especialmente en televisión y prensa gratuita), pero el discurso de los medios - sobre el que existe una fuerte suspicacia, por sus servidumbres ideológicas y políticas - es confrontado constantemente con su propia experiencia concreta, y es reelaborado día a día desde una perspectiva ideológica en el contexto relacional más próximo.

A pesar de ello, creemos que las tesis de Lizcano presentan un enorme interés. Este autor señala cómo la proliferación de metáforas sobre la crisis en los discursos expertos — que se alejan del lenguaje y conceptualización 'científica': hablando de 'brotes verdes', del 'tsunami financiero', de 'sequía crediticia', de la 'metástasis en la economía real', de la 'elevada exposición a activos tóxicos', etcétera- “...lejos de socavar la credibilidad de tales discursos" consiguen una mayor proyección y aceptación social de los mismos (y sobre todo, de su diagnóstico de la crisis). Las metáforas pasan "....a incorporarse tanto al lenguaje común, como al lenguaje de políticos y sindicalistas o a los debates de la prensa especializada en asuntos económicos y financieros" (Lizcano, 2012: 225). En el caso de las clases populares, un elemento muy importante es la mayor comprensibilidad que ofrecen las metáforas con respecto a sus formulaciones académicas equivalentes, más precisas, pero mucho más abstrusas para el ciudadano promedio. De todas maneras, para Lizcano (ibid.: 226) "Los discursos expertos sobre la crisis económica no pretenden tanto buscar explicaciones racionales que den cuenta de la misma, cuanto suscitar en la población una serie de emociones que muevan a la aceptación de unas medidas

${ }^{8}$ Un conocido texto que explora el papel central de los medios de comunicación en el proceso de construcción del miedo social y las crisis, contextualizándolo en estrategias de ejercicio de poder y control social, es el de Altheide (2001). 
políticas que, sin ellas, provocarían un fuerte rechazo". ${ }^{9}$ Es ahí donde finalmente Lizcano - cuyo análisis metafórico parece remitirnos al poder persuasivo que moviliza la hegemonía en la propuesta de Gramsci- observa la clave de la generalizada pasividad resignada de la población, paradójico conformismo apático en el contexto de una crisis dramática en sus dimensiones y consecuencias sociales, y ante la generalización de políticas de recorte con efectos sociales también demoledores.

Quizá la limitación de la aportación de Lizcano resida en que no atiende en su análisis al sistema de discursos —...y al propio contexto social — que sirven de matriz contenedora/generadora en el proceso de elaboración de las metáforas, y que también intervienen en el propio proceso de recepción y atribución de sentido $-\mathrm{y}$ posible aceptación, o rechazo - de las metáforas. Al no acceder al nivel de un verdadero análisis del discurso, su análisis metafórico parece presuponer indirectamente la existencia de un único discurso experto (monolítico, sin fisuras), y también una recepción 'clónica' y mecánica (de mera absorción) por parte de la ciudadanía. Parece diagnosticar Lizcano una aceptación absoluta de esas metáforas por parte de la ciudadanía (independientemente de su posición social, su situación vital concreta, sus coordenadas ideológicas, etc.), lo cual no es verosímil. Existe una gran diversidad de marcos interpretativos. Al no articular posiciones discursivas, alrededor de su hermenéutica de las metáforas circulantes sobre la crisis (las metáforas se inscriben en discursos, condensan significados claves para entender posiciones discursivas, pero no son discursos en sí mismas), su análisis termina siendo 'romo', aunque extraordinariamente sugerente.

\section{La percepción social de la crisis: las causas y los responsables}

Como señala Domínguez (2000) "La crisis no es y no puede ser meramente un proceso histórico objetivo, es también un proceso histórico "subjetivo»". Y precisamente en este artículo nos interesa profundizar en la percepción subjetiva de los actores más afectados por la crisis, aquéllos que han pasado a engrosar la lábil categoría de los 'nuevos pobres'. Resulta evidente, que la percepción de la crisis por parte de los sujetos sociales, forma parte indisoluble de la propia crisis, y de su devenir (Augé, 2012: 70). En la misma dirección Habermas (1995: 15) recuerda que "la crisis es inseparable de la percepción interior de quien la padece". Es evidente que toda crisis en su desarrollo está atravesada por un proceso de subjetivización dinámico - que es crítico para entender su configuración social y su desarrollo. Ese proceso de subjetivización se produce irremediablemente en el campo de lo social,

${ }^{9}$ Acerca de las metáforas como analizadores sociales, véase la aportación ya clásica de Lakoff y Johnson (2004) [e.o. 1980] y entre las diversas aportaciones de E. Lizcano, puede consultarse Lizcano (2006). 
fundamentalmente en el espacio de la interacción social. Por lo tanto, a pesar de que "con las crisis asociamos la idea de un poder objetivo que arrebata al sujeto una parte de la soberanía que normalmente le corresponde" (ibid.), el sujeto - y los grupos sociales - viven y sobreviven la crisis, y haciéndolo afrontan estrategias y dinámicas de reconstrucción.

La crisis posee una dimensión material y social que trasciende lo económico, que se percibe al nivel de la vida cotidiana. La 'vivencia' íntima de la crisis, al margen del desencadenamiento de eventos más o menos fortuitos como perder el empleo, depende de factores diversos - innumerables-, muchos de los cuales tienen que ver con la posición social ocupada (en términos de clase, género, edad, nivel educativo, nacionalidad, etc.), pero también se entrelaza con la trayectoria vital (esto es, por dónde se ha ido pasando: maternidad, separaciones, adquisición de vivienda, etc.), sin olvidar la influencia de la red relacional. Son estos aspectos que se reclaman y condicionan entre sí. Así, la crisis se vive de formas muy diversas (también entre los nuevos pobres); se sufre - $\mathrm{o}$ no-, y esa experiencia vivencial (inmediata y/o mediata) es fundamental en la elaboración de los discursos sobre la crisis (cómo se explica), e incide, al margen de los eventos y procesos sociales (políticos, macroeconómicos), sobre la re-definición y re-construcción de la propia crisis.

Pasemos a considerar cómo perciben los nuevos pobres la crisis. En el contexto de una crisis compleja y multidimensional, sus explicaciones tienden a la diversidad de enfoques y niveles, aunque al mismo tiempo están fuertemente estereotipadas. En general encontramos estrategias explicativas de carácter multidimensional en la que las 'ideas fuerza' son limitadas y se integran en forma de precario 'patchwork', o conjunto de retales débilmente hilvanados entre sí.

El elemento central de la vivencia de la crisis es la incertidumbre, que se refleja nítidamente en los discursos de los sectores de las clases populares más afectados y que integran el grupo más numeroso entre los nuevos pobres. En un contexto de fuerte incertidumbre, los discursos tienden a ser más tentativos, principalmente con respecto al futuro, pero incluso cuando se aborda la explicación de la crisis. Así los discursos, recogen y reelaboran en ocasiones los planteamientos de los expertos (proyectados por los medios), y movilizan tópicos (explicaciones que simplifican la complejidad circundante a la hora de hacer comprensible la realidad, generando sentido).

Domina la percepción y conceptualización de la crisis en clave local (considerando preferentemente el marco español). Si nuestras clases empobrecidas tuvieran que señalar un único 'culpable', esta sería sin duda la clase política. Más allá del enorme consenso de la culpabilidad de los políticos — sobre la que regresaremos más adelante-, aparecen otros culpables secundarios: ciudadanía, bancos, inmigrantes. Tampoco se olvida que los españoles — individualmente consideradoshan cometido excesos (concretados en el hiperconsumo y el sobreendeudamiento, conectados entre sí) que también se ubican en la base de la crisis. Resulta llamativo el papel relativamente secundario que ocupan los bancos en este marco explicativo. A pesar del enojo que suscita el rescate de los bancos (y ahí el acuerdo es total en la 
segunda fase de nuestro trabajo de campo), éstos tienden a no aparecer como responsables. No hay un relato de la crisis - salvo casos absolutamente excepcionales- que remita a la crisis financiera de 2007. El marco explicativo es nacional, y en el ámbito económico, la referencia central es el sector inmobiliario.

La importancia otorgada a la base individual en la interpretación de las causas de la crisis, se inscribe y toma sentido en un proceso de 'psicologización' de los procesos y problemas sociales, que si bien no es nuevo, se expresa con nitidez en el contexto de la crisis. En este caso, se ha producido un patente proceso de psicologización de las causas de la crisis, que en ningún caso es inocuo en términos ideológicos y que ha sido promovido desde las instancias de poder económico y político. Ya Sennett anticipó a mediados de los años setenta del pasado siglo el vector de privatización al hacer referencia al "desgaste de la vida pública" (Sennett, 2001: 25). El sociólogo norteamericano, identificaba el advenimiento de una ideología de la intimidad que trocaba las categorías políticas en categorías de orden psicológico (ibid.: 568). Para Sennett "se ha producido una confusión entre la vida privada y la pública; la gente está resolviendo en términos de sentimientos personales aquellas cuestiones públicas que sólo pueden ser correctamente tratadas a través de códigos de significado impersonal" (ibid.: 24).

Inmersos en un potente proceso de individualización, la búsqueda de "soluciones biográficas a problemas sistémicos" (Beck, 2001) se convierte —en el marco de la crisis - cada vez más (ante la imposibilidad de encontrar soluciones individuales en el mercado de trabajo, con respecto a la vivienda, etc.), en la búsqueda de estrategias de 'gestión' psicológica para no caer en la desesperación, en el extremo, apoyadas incluso en la farmacologización psiquiátrica (como aparece expresado en nuestro campo). Los problemas sociales se reducen y reconvierten en problemas de gestión psíquica de situaciones personales adversas (reflejo de un potente mecanismo de subjetivización), lo cual refleja el reforzamiento de ciertos dispositivos de control social, que residen y funcionan a nivel individual. Esta psicologización converge a nivel ideológico con el discurso de responsabilización individual de los sujetos, que incide en la asunción de los fracasos como propios, y la presencia de discursos - entre las propias clases depauperadas - centrados en la adaptabilidad del sujeto con respecto a las condiciones dadas. Son procesos y discursos que finalmente dificultan sobremanera la articulación de estrategias colectivas y la movilización social.

\subsection{La universalización de la culpa: la responsabilización individual}

La atribución de cuotas de responsabilidad a todos y cada uno de los sujetos sociales en la génesis y desarrollo de la crisis, es una argumentación que permea los discursos producidos en la mayoría de nuestros grupos. Estaríamos ante una evidente muestra de la potencia y éxito del discurso del "reparto social de la responsabilidad de la crisis" (Cadahia y Velasco, 2012: 9), proyectado desde las posiciones de poder político y económico; éxito que, por otro lado, justificaría y facilitaría la imposición, y asunción resignada, de los recortes generalizados. 
La "ideología de la socialización de la responsabilidad" (Velasco, 2012: 216), propone en realidad una socialización de la culpa que se desliza a la baja, descentra el papel de los bancos, del capitalismo financiero y de las elites económicas (es decir, de las instituciones y del orden económico) y 'centra' el papel de los ciudadanos de 'a pie' desde una perspectiva individual. La sociedad aparece como un sumatorio de individuos, como simple agregado en el que todos los agentes tienen un papel equivalente. Resurge por lo tanto la perspectiva del mercado como una institución dependiente de la racionalidad micro: si no ha funcionado adecuadamente es porque la racionalidad ha fallado por la base. Realmente el proceso fue el inverso, fueron los 'excesos' en la cúspide (orientados hacia la maximización del beneficio) los que arrastraron a los consumidores de la base (que son mayoritariamente los que perdieron, y siguen perdiendo, empleos, pequeños ahorros, casas humildes, etc.). No hay otro argumento que esté tan presente en los discursos de las clases populares empobrecidas, excepción hecha de la responsabilización de los políticos.

\subsubsection{Los excesos de la cultura consumista y las conductas consumistas irracionales}

En el ámbito del consumo se produce una clara reactualización del mito fáusti$c o^{10}$, que se articula en la ubicua afirmación "hemos vivido por encima de nuestras posibilidades" que se repite obsesivamente en buena parte de nuestros grupos de discusión. Esta fórmula refleja el conflicto fáustico entre el afán de acumular y el de disfrutar (Lucas y Ortí, 2004), central en el modelo de consumo contemporáneo. Por otro lado, también refleja con nitidez, la ofensiva ideológica liberal, que paradójicamente termina disolviendo la racionalidad intrínseca del consumidor que propone la teoría marginalista. Así, se realiza una redistribución de las responsabilidades asimétrica, los bancos terminan siendo víctimas de la voracidad de los consumos de sus clientes, cuando los riesgos fueron valorados y asumidos (y básicamente potenciados) por las entidades financieras, supuestamente adoptando criterios técnicos.

Según Žižek (2011: 44) la condena generalizada a la cultura de la avaricia y del consumo excesivo, esconde una potente operación ideológica. La compulsión por la expansión, que ocupa una posición estructural central en el sistema capitalista, se transforma en una cuestión de 'pecado personal', una propensión psicológica privada, que casa excepcionalmente bien con la fórmula 'vivir por encima de mis posibilidades', lo que remite no sólo a una falta de previsión y realismo, al asumir un riesgo excesivo, sino finalmente a un comportamiento inmoral, que ha conducido al desastre. Se igualan así de facto la ingeniería y las triquiñuelas financieras de los bancos de inversión, con niveles de apalancamiento y riesgo desorbitados, que

${ }^{10}$ Obras que analizan el mito fáustico son la de Berman (2004: 28 y ss.) y Lukács (1968). Ambas se concentran en el análisis del Fausto de Goethe, menos 'materialista' que las versiones literarias previas del mito, y más ligado al autodesarrollo personal (vid. Berman, ibid. 31). 
jugaron a un capitalismo 'de casino', con el pago a plazos de un televisor por parte de un mileurista sin contrato indefinido.

Así pues, todos somos culpables. La crisis aparece como resultado de la agregación de comportamientos individuales de derroche y sobreendeudamiento ("nos ha gustado mucho gastar" E6). Encontramos una argumentación que apunta el consumo descontrolado como elemento explicativo de la situación de penuria actual y de las privaciones ("...tanta burbuja, tanto coche nuevo, cada cuatro años esto nuevo, lavadoras en la calle, todo tirado" GD2), un comportamiento de consumo desaforado, un 'despilfarro popular' de la gente corriente, que no se adecuaba a las propias posibilidades económicas, y que se opondría a lo que se hacía "antiguamente", el comportamiento económico caracterizado por el consumo contenido, el ahorro, la previsión y el realismo económico. En ese modelo de consumo descontrolado habrían participado todos los actores sociales. Así pues, encontramos una verdadera equiparación de responsabilidades, todos (obreros, banqueros, etc.) 'hemos vivido por encima de nuestras posibilidades'. Esa aceptación de irresponsabilidades individuales implicaría un gran éxito de penetración del modelo explicativo liberal, según el cual el fallo no reside en el mercado, sino en los consumidores que han desarrollado conductas y estrategias de consumo irracional (entrando por otro lado, en contradicción con las premisas teóricas básicas del marginalismo neoclásico, que concibe a los consumidores como actores eminentemente racionales).

Pero, si revisamos nuestro material empírico, encontramos más bien, cómo la norma de consumo no se identifica con personas 'alocadas', sino más bien, con consumidores acostumbrados a los equilibrios, a vivir con relativamente pocos recursos: "yo he vivido siempre con pocos recursos, o sea mi salario es, siempre ha rondado entre ochocientos, novecientos euros, y bueno, pues tenía para pagar mi..., mi casa [en alquiler], tampoco para pegarme grandes fiestas pero bueno, tampoco ha sido mi pretensión" (GT1 ${ }^{11}$. Comportamientos hacendosos y previsores de quien no ha vivido al límite: "me he encargado de hacer amortizaciones" (GT2); "sabes que eres obrero y te cuesta ganarlo" (GD2); "...tenía mucho ahorrado, de que siempre he sido trabajador y me ha gustado ir, pues si te pasa algo, es ir ahorrando, durante mi vida he ahorrado mucho, la verdad", "siempre con mucha cabeza" (E6). No obstante, sí existe un segmento minoritario más consumista - especialmente presente entre los jóvenes - , que reconoce un consumo 'al límite' de sus posibilidades económicas, 'subyugado' por las tarjetas de crédito, que potencian el 'des-

${ }^{11}$ Alonso et al. (2011: 361-362) coinciden con nuestra apreciación al señalar que pese al discurso dominante entre las clases supraordinadas con respecto a las clases populares que les identifican con pautas de consumo descontroladas e irracionales (que se dejan arrastrar fácilmente por el consumismo y los excesos hedonistas), sus prácticas dominantes son exactamente las contrarias. Pero las clases populares más vulnerabilizadas han sido muy permeables a estos argumentos, como muestra nuestro trabajo de campo. Existe una patente autoculpabilización. 
control' en el gasto: "si quería sacar con la libreta tenía que ir al banco, que te dieran el dinero: pues claro, ¿qué pasa? Que siempre iba con lo justo, claro, cuando tuve la tarjeta, no pasa nada, yo saco, claro, yo sacaba en todos los bancos..." (GD6). Es este segmento de jóvenes consumistas, el que más se ha insertado en un modelo de consumo puramente hedonista, amnésico y descontrolado: “...porque tienes muchas ganas de gastar, ya como estás todo el día intentando ahorrar, ahorrar... en cuanto lo tienes te lo gastas de golpe" (GD6).

\subsubsection{Los déficits y los errores estratégicos del sujeto individualmente considerado}

Encontramos en ocasiones la autoculpabilización asociada a déficits o errores "estratégicos, usualmente por no aprovechar adecuadamente ciertas oportunidades ("a lo mejor no aproveché en su momento ciertas oportunidades laborales" GT1). Son valoraciones realizadas a posteriori, en el contexto de una crisis que se prolonga indefinidamente ante sus ojos, a la luz de lo cual ciertas decisiones tomadas en el pasado son ahora concebidas como errores. Cualquier decisión, aunque fuera racionalmente sopesada, es retrospectivamente cuestionada, y pasa a ser simplemente irracional ("ahora me arrepiento de haberme... de no haberme tragado mi orgullo y haberme quedado, porque seguramente tendría trabajo a día de hoy" GT2). Hemos de señalar que las decisiones que ahora se consideran 'fallidas' se tomaron mayoritariamente desde una óptica racional: en función de expectativas laborales, por un sentido de integridad profesional, por mantener una carrera laboral coherente, etcétera.

\subsection{La clase política y los partidos políticos: entre la corrupción y la incom petencia}

Si tuviéramos que identificar en los discursos de los 'nuevos pobres' un responsable central a la hora de explicar la crisis, no cabe ninguna duda que habría que dirigir la mirada hacia el nivel de lo político. Los grandes responsables son los políticos - la clase política en su conjunto-, y por extensión, los partidos.

Nuestro material empírico da cuenta de una situación de enorme desprestigio de la actividad política en general, y concretamente de la clase política, desprestigio que tiende a contagiarse a las instituciones (y que se proyecta también sobre los sindicatos). Ese descrédito hace que se constituya como lugar común el recurso entre las clases populares empobrecidas - a formulaciones del tipo "yo de política no entiendo" (GD2), que aparecen recurrentemente en grupos y entrevistas, que oculta bajo una aparente 'ignorancia' o neutralidad, lo que no es sino un fuerte rechazo y hartazgo con respecto al funcionamiento de la política. Este hartazgo camuflado bajo el desconocimiento - se asocia frecuentemente a la ausencia de participación política — que se concreta restrictivamente en los procesos electorales-: "yo... mira nunca he votado, nunca, jamás, ni estas elecciones, ninguna, no entiendo..." (GD2). Domina la percepción de que la actividad política no se orienta hacia el bienestar de los ciudadanos; su lógica es otra, la perpetuación de la clase política y sus privilegios. 
Hay una visión relativamente generalizada que identifica la subordinación y sometimiento del sistema democrático al poder de las grandes empresas (los estados son "marionetas" GT2), y de la connivencia entre las elites económicas y políticas. Se trata, a priori de un principio de gran potencialidad crítica, pero su transformación en tópico discursivo, contribuye a desactivarlo, al concretarse mayoritariamente en posiciones discursivas asociadas a la desmovilización e indolencia política, en colectivos descreídos y apáticos que están 'de vuelta de todo'.

Entre los segmentos 'pobres' de clases populares encontramos un ataque generalizado y virulento a la clase política española (aunque al mismo tiempo muy personalizado, al identificar a los grandes culpables) que se articula en torno al diagnóstico de una corrupción generalizada. Quizá sólo se escapan de esta posición las mujeres pobres con cargas familiares, cuya agenda se ubica casi exclusivamente en la supervivencia cotidiana, en su rol materno y que presentan una visión del mundo escasamente política. Entre los miembros de las clases medias funcionales ${ }^{12}$ en situación de pobreza, el análisis es notablemente diferente, para ellos, el problema político fundamental tiene que ver esencialmente con problemas de gestión y déficits de profesionalidad (incompetencia). A diferencia de las clases populares (clase obrera y clase media baja), no identifican un problema generalizado de inmoralidad o falta de voluntad - sin que esto suponga negar la existencia de corrupción-. Así, los problemas de la clase política española tienen que ver para este segmento con déficits de capacidad y liderazgo ("falta gente capaz y competente a nivel político [...] sobre todo en la política... me parece indignante que nos dirija gente... como la que nos dirige" GT2).

Los que explotan a los ciudadanos son los políticos ("se están beneficiando a costa nuestra, sacándonos, chupándonos" GD5). Esa imagen de la explotación vampirizadora y parasitaria (identificada con el robo) no aparece en ningún caso en nuestro trabajo de campo asociado a la figura del empresario o el 'banquero'. El empresario puede imponer condiciones de trabajo denigrantes, e incluso inhumanas, pero en ningún caso roba al trabajador. Se trata de una cuestión especialmente significativa.

En general, circula la idea de una situación de corrupción generalizada, una verdadera "cleptocracia" (Nieto, 2008: 154), concibiéndose la política como un espacio de oportunidades personales. Resulta llamativo constatar como el predominio del interés individual se liga más intensamente en los grupos y entrevistas a la

${ }^{12}$ Siguiendo a Alfonso Ortí (cfr. Colectivo Ioé, 2007: 16). "Las clases medias funcionales son trabajadores por cuenta ajena que ocupan funciones de mediación y gestión organizativa dentro del aparato del Estado o de las cada vez más extensas burocracias empresariales. Estas clases medias «ocupan aquellas posiciones jerárquicas de control, poder organizativo, liderazgo y asesoramiento (como directivos o gerentes, cuadros superiores o técnicos y profesionales altamente cualificados) que convierte en estratégica su histórica función de mediación (a veces políticamente decisiva) en las luchas entre capital y trabajo, y en general en todos los conflictos sociales e ideológicos»»". 
actividad política que al propio funcionamiento del mercado. Se contrapone la política al interés general (al bien común). Podríamos hablar de una posición discursiva transversal, que apunta la corruptela de los políticos que gobiernan buscando el beneficio personal ("lo que estamos haciendo es votar por corruptos una y otra vez" GD2) identificando un robo generalizado al pueblo.

Por otro lado, esta percepción de un estado de corrupción generalizada en los niveles elevados de la administración, focalizada en los políticos (la figura del funcionario corrupto no aparece de forma tan central en los discursos, sí la del funcionario displicente), puede terminar justificando las conductas corruptas a un nivel inferior (Cockcroft, 2012). De ahí que — aunque no sea un elemento central discursivamente - en los grupos aparezca con relativa frecuencia una cierta justificación, al identificarse una especie de 'ethos nacional' tendente a la corrupción. Partiendo de algo así como un 'todos haríamos lo mismo', 'todos tenemos un precio', aparece un planteamiento ambivalente que a la postre disuelve el potencial de crítica (al margen de que en ocasiones en los grupos la reelección reiterada de políticos corruptos, haga que la responsabilidad última se haga recaer en los propios electores). Así pues, a pesar de la virulencia del ataque a los políticos, encontramos una cierta resignación (implícitamente se trasluce una elevada tolerancia social hacia las corruptelas). ${ }^{13}$

Para el segmento de nuevos pobres movilizados, parecería que la crisis es correlato más de las deficiencias del modelo democrático (y especialmente electoral), que de la crisis institucional o de un clima de corrupción generalizada (más bien, estos son subproductos de las deficiencias democráticas). Para ellos existe una distorsión de la voluntad general, eso impide el cambio político y el control democrático. No obstante, encontramos una patente debilidad en los argumentos. Al centrarse casi exclusivamente en el análisis de la representatividad del voto (reflexionando sobre la abstención, etc.), 'olvidan' —en parte- hacer un diagnóstico más completo de la situación política y del sistema democrático que trascienda 'lo electoral'.

\subsection{Las disfunciones de la economía capitalista}

Aunque es frecuente que en nuestros grupos de discusión y triangulares se vincule la aparición y devenir de la crisis con la articulación del sistema económico capitalista, no podemos hablar ni mucho menos de una generalización de posiciones anticapitalistas, todo lo contrario, ni siquiera entre los que en ocasiones -

${ }^{13}$ Esta ambivalencia nos remitiría a otros análisis teóricos más 'provocadores' que observan finalmente la corrupción como un elemento estrictamente funcional con respecto al sistema de dominación. Es el caso de Surya (2012: 12), que apunta que “...los casos de corrupción sólo perjudican en apariencia a la dominación. Son, muy por el contrario, el medio del que ésta se ha amparado inmediatamente para sanear las condiciones de su ejercicio". 
usualmente entre el sector movilizado - realizan un ataque directo, con enunciaciones del tipo "yo reniego de un sistema capitalista" (GT1). En gran medida tales cuestionamientos son expresados más como síntoma de desencanto y frustración, que como expresión de posiciones ideológicas 'asentadas' que 'cuestionen' realmente los elementos estructurales del orden económico y - por extensión- del orden social. El problema se ubica en la implementación del modelo, no se cuestionan las instituciones económicas básicas (con el mercado y el sistema financiero a la cabeza). Se plantea en ocasiones la irracionalidad del escenario concreto (por ejemplo, millones de casas vacías, versus centenares de miles de familias desahuciadas y desalojadas) más que la irracionalidad del orden económico en su conjunto.

Desde las posiciones liberales más ortodoxas, que se concretan en el sector de orientación más meritocrática de las clases medias funcionales en paro, también se dirige la mirada hacia el mercado, pero no para cuestionarlo, sino para indicar que ha abandonado su 'naturaleza': si no funciona como debiera es porque padece una cierta enfermedad ("el mercado se ha trastornado" GT2). Se hace referencia a una especie de estado de enajenación transitorio (suponiendo una patente personalización del mercado), el mercado está fuera de sí, alterado, estamos ante una lógica distorsionada. El problema no está en el mercado como tal, en su esencia (es decir en la institución), sino en su estado.

Solo en el sector más movilizado de los nuevos pobres (que coincide mayoritariamente con la fracción crítica progresiva), se resalta la dimensión ideológica de la organización y sistema económico, y llevan la responsabilidad económica a primer plano. La centralidad de la crítica se dirige hacia el sistema capitalista, a diferencia del grueso del colectivo de nuevos pobres que focaliza su atención y crítica (de manera obsesiva) sobre los políticos - nacionales-. La fracción crítica progresiva, constata desde la decepción, que se está imponiendo la visión conservadora en la gestión política de la crisis, garantizando los intereses del gran capital, y que las expectativas de cambio institucional profundo (en la esfera de la economía y de la política) que se habían levantado al comienzo de la crisis se desmoronan: "al principio de la crisis se hablaba mucho de un cambio de sistema, y al... al final no se está hablando nada" (GT2). Para ellos, el debate sobre las causas de la crisis se ha diluido, dando paso al monólogo de los mercados (y de la política sometida a los dictados de esos mercados), y a estrategias de acallamiento y represión (y ahí, las referencias a la represión policial del 25-S, como punto de inflexión, son reiteradas).

Las posiciones expresamente anticapitalistas (minoritarias), muestran en ocasiones una fuerte inconsistencia interna, resultan contradictorias en su articulación discursiva, ya que las críticas globales al modelo económico se combinan con estrategias vitales adaptativas. El diagnóstico 'realista' que descarta la posibilidad de una 'desaparición' del sistema capitalista a corto o medio plazo, conduce en ocasiones a la fracción anticapitalista a posiciones enormemente paradójicas. Por ejemplo, en nuestro GT1, se articula una crítica feroz contra los mercados financieros (especialmente focalizado en el mercado de la deuda soberana) que se simultanea con una aceptación aparentemente acrítica del beneficio empresarial y la desigualdad social: "yo no voy a entrar en la dinámica de que un empresario tenga que 
llevarse mucha pasta, a mí me da igual la pasta que se lleve, siempre y cuando en su empresa se cumpla lo que se tenga que cumplir" (GT1). Así, la lucha de máximos contra el capitalismo se reconduce (quizá de manera coherente con una aspiración expresada entre los movilizados de 'no quemarse') hacia la exigencia del respeto de la legalidad vigente, dejándose de lado la exigencia de 'justicia' y abandonando en gran medida conceptos 'clásicos' de análisis como el de explotación. Si resulta sorprendente esta posición es porque tradicionalmente desde las posiciones anticapitalistas la regulación política se ha entendido como materialización de los intereses de las elites económicas.

\subsection{El 'chivo expiatorio': los inmigrantes y el acaparamiento de recursos limitados}

En los discursos de las clases populares empobrecidas, aparece una constante: los inmigrantes son responsables directos de la situación de crisis actual. No deberíamos sorprendernos, ya que como recuerda Morin, en una situación de crisis, "la búsqueda de responsabilidades se divide [...] en dos ramales antagónicos, uno que trata de reconocer la naturaleza misma del mal, el otro que persigue al chivo expiatorio al que inmolar, y naturalmente, se multiplican los culpables imaginarios, lo más frecuente entre marginados o minorías" (Morin, 1995: 168).

En estos discursos - que derivan a posiciones xenófobas, e incluso en ciertas ocasiones racistas: "España es un nido de ratas, España es un nido de ratas ivale?" (GD2) - a los inmigrantes se les desposee de su capacidad productiva (lo que aportan y aportaron en términos de riqueza a la economía española) para insistir en la dimensión de apropiación de los recursos escasos (ya sean puestos de trabajo, prestaciones, ayudas, etc.), recursos que, en justicia, deberían corresponder únicamente a los españoles. Pero, la argumentación sobre la apropiación, no suele partir de la consideración de la contracción por el lado de la oferta en el contexto de la crisis, y de su gestión política (destrucción de empleo, recortes en las políticas sociales), lo que implicaría una reducción previa de los recursos a repartir, sino que se tienden a considerar los recursos existentes como una constante en el tiempo, y desde ahí, se procede a culpabilizar a los inmigrantes de la propia carestía de recursos en términos de simple desplazamiento: algo así como 'nos están quitando lo que es legítimamente nuestro'. Simbólicamente aparecen imágenes de invasión e incluso de aniquilación ("los extranjeros nos tienen... comidos y ya está, nos tienen absorbidos los extranjeros" GD2), que se relacionan a nivel macro con la pérdida de la 'esencia nacional'.

Entre los varones obreros, se presta especial atención al ámbito laboral. Los inmigrantes serían los responsables últimos del proceso de degradación del mercado de trabajo (del enorme excedente de mano de obra en el mercado laboral español), y por supuesto, de la degradación de las condiciones de trabajo de los últimos años. La crisis estructural se transforma en un problema de flujos, más concretamente de falta de control de los flujos por parte del Estado ("han entrado por todos los lados" GD2). Se llega a una conclusión autoevidente, sin inmigrantes habría trabajo para todos, lo cual implica una distorsión burda de la situación de crisis: "Mira, cinco 
millones de parados, en España ¿no? Y qué casualidad, que hay cinco millones de extranjeros en España" (GD2).

Ante la ausencia de un modelo interpretativo global (satisfactorio) de la crisis, la explicación deriva hacia la identificación de un 'chivo expiatorio' concretado en la figura del extranjero. Para los obreros en situación de pobreza - especialmente aquellos adscritos al sector de la construcción - la situación actual da cuenta de un proceso de invasión y colonización por parte de los extranjeros que se concreta en diversos ámbitos, especialmente el mercado de trabajo, pero también en los espacios públicos, el acceso a ciertas prestaciones, etc. Su concentración obsesiva sobre el colectivo de inmigrantes responde a una realidad de competencia directa $-\mathrm{y}$ cada vez más dura en el contexto de la crisis - con éstos, dado que aspiran al mismo tipo de trabajos, lo que en un marco de sobreabundancia de mano de obra, facilita la degradación de las condiciones de trabajo. En el extremo, en los discursos son los españoles los que se convierten en una minoría discriminada.

La clase media baja empobrecida se concentra en la consideración del acceso a recursos por parte de los inmigrantes. El acceso a las ayudas no depende de condiciones objetivas, los inmigrantes tienen más derechos simplemente por el hecho de ser extranjeros ("todo lo que ha venido de fuera tienen más ventajas que nosotros" GD3), lo cual en sí mismo carece de sentido, pero es un discurso que circula fluidamente sin que en ningún caso se cuestione. No se critica la escasez de servicios, el infradesarrollo de servicios y prestaciones, su cuantía ridícula, la debilidad del Estado de Bienestar, ni tan siquiera se habla de recortes, el diagnóstico es un simple desplazamiento.

Que se trate de un discurso hegemónico no significa que no haya sectores minoritarios (incluso en el seno de la clase obrera) que articulen una posición comprensiva con respecto a los inmigrantes, que entiendan sus motivaciones, y sus problemas. Encontramos algunas posiciones valorativas: "Yo creo que los inmigrantes son personas muy válidas" (GT2). Para otros colectivos, el tema de la inmigración no es un tema relevante a la hora de configurar su vivencia de la crisis (por ejemplo, entre las mujeres de familias monoparentales, y entre las clases medias funcionales empobrecidas), lo cual no implica que desarrollen siempre discursos de tolerancia plena o de indiferencia.

\section{Estrategias y propuestas para salir y/o amortiguar el impacto de la crisis}

En este apartado consideraremos estrategias que aunque frecuentemente se integran en las prácticas cotidianas, en otras ocasiones solo circulan discursivamente como lugares comunes, incluso como verdaderas fantasías y mitos. En principio son estrategias 'distintivas', pero no tienen por qué ser excluyentes entre sí, ni a nivel discursivo ni práctico. 


\subsection{Las estrategias individuales}

Las estrategias individuales que pretendemos explorar, se ubican en las antípodas de las propuestas 'políticas' de superación de la crisis. Nos hallamos ante tácticas de adaptación funcional y de supervivencia en un contexto adverso. En ocasiones se trata de estrategias encaminadas simplemente a gestionar la angustia y la desesperación asociada a la cotidianidad, y ahí se abre el espacio para la huida. Incluso entre el sector más crítico, la minoría progresiva movilizada, cuando se trasciende el análisis concreto de la situación de crisis, el horizonte de las soluciones tiende a circunscribirse casi exclusivamente a lo individual. En ese instante, se abandona la referencia a la movilización colectiva, la grupalidad y la transformación social, para pasar a perfilar - tomando la formulación de Beck- soluciones biográficas a contradicciones sistémicas.

Las estrategias individuales basculan como puntos extremos entre 'la lucha' y 'el enclaustramiento apático', en configuraciones muy diferentes. El rol luchador no se configura como una estrategia política, se trata de una lucha solitaria por la supervivencia cotidiana (en el día a día), arquetípicamente concretada en la figura de las 'madres coraje', responsables de familias monoparentales pobres cuya cotidianidad se corresponde con un imperativo ineludible: sacar adelante a los hijos.

Las salidas individuales 'competitivas' (meritocráticas) suponen el bloque fundamental de las estrategias, lo cual es lógico en un contexto de galopante individualización social. Bauman, señala el avance de la tendencia: "librados cada vez más a sus propios recursos y a su propia sagacidad, los individuos se ven obligados a idear soluciones individuales a problemas generados socialmente, y se espera que lo hagan como individuos, mediante sus habilidades individuales y sus bienes de posesión individual. Tal expectativa los enfrenta en mutua competencia y crea la percepción de que la solidaridad comunitaria es en general irrelevante, si no contraproducente" (Bauman, 2011: 28). Sigue apuntando Bauman (ibid.) que "esta «individualización por decreto» vuelve inexorable la diferenciación y polarización entre las oportunidades individuales; más aún hace de la polarización de perspectivas y oportunidades un proceso que se impulsa y se acelera a sí mismo". En sentido estricto (y mucho más en el caso de los sujetos integrados en la categoría de nueva pobreza) nunca serán 'soluciones', sino estrategias de supervivencia, en marcos hostiles de privación y ausencia total de posibilidades.

\subsubsection{El planteamiento meritocrático individual}

En un primer momento la dureza y profundidad de la crisis, pone en evidencia y deslegitima el pretendido modelo meritocrático y sus adherencias ideológicas (la ficticia igualdad de oportunidades entre otras), las clases populares empobrecidas constatan la farsa de un modelo que pretendidamente valora y recompensa en función de la capacidad, el mérito y el esfuerzo. Pero, sin embargo, los planteamientos meritocráticos no desaparecen, en gran medida se reciclan, se adopta una orientación cínica, descreída, pero persisten salvo para ciertos colectivos, que simplemente tienden a arrojar la toalla (son los acabados), o buscan refugio en entornos grupales alternativos. Así, entre los nuevos pobres las estrategias merito- 
cráticas para enfrentar la crisis no son, ni mucho menos, una excepción. Aunque sí es cierto que aparecen en distintas configuraciones discursivas.

\section{A) La meritocracia estratégica y esforzada de los inmigrantes: querer es poder}

Entre los inmigrantes encontramos un sector meritocrático, integrado especialmente por aquellos que lograron - aunque hayan atravesado posteriormente un proceso de pérdida - una inserción laboral acorde a su nivel formativo de origen. Según estos inmigrantes, para conseguir el éxito laboral, es especialmente importante la actitud personal, el labrarse con esfuerzo una trayectoria laboral coherente. En este contexto a ellos/as no les valen las coartadas de sus compatriotas que se justifican en las actitudes xenófobas de la población española y la discriminación institucional. La xenofobia, justifica este segmento (relativamente minoritario), es en gran medida la respuesta a la actitud del inmigrante (renuente a mostrar voluntad de integración). Si te esfuerzas, si haces bien las cosas, si reúnes credenciales, lograrás la integración laboral y el respecto de la población autóctona; ese es su mensaje. Es necesario partir de un planteamiento realista, tomar conciencia de dónde estoy, y de quién soy yo: un extraño, un sujeto ajeno, que ha de luchar por hacerse un lugar. Así, la responsabilidad fundamental en el proceso de integración social recae sobre el inmigrante, a la hora de insertarse laboralmente (en un puesto acorde a su categoría profesional), o de conseguir superar la crisis. En estos casos, los éxitos profesionales, que se han esfumado en el contexto de la crisis, se reactualizan ilusoriamente en el presente: "al final he llegado donde he querido, en un país extranjero, a mí no me han hablado nunca mal, no me han tratado nunca mal" (GD4).

\section{B) Los jóvenes y la expectativa promocional a través de la formación reglada}

Entre los jóvenes de las clases populares, con bajos niveles de estudios, se hace especial hincapié en la formación como vía - idealizada - para enfrentar la crisis. No obstante, toma más bien la forma de un deseo, ya que una parte importante de los jóvenes de clases populares no dispone ni de las capacidades ni de los recursos necesarios, para enfrentar un proceso intenso y prolongado de formación. Entre los jóvenes de clase obrera encontramos una posición ambigua. Ven la salida en la formación, pero creen que el espacio de formación debería ser la esfera del trabajo. Frecuentemente piensan que los jóvenes más formados, están aceptando trabajos de menor nivel y bloquean sus salidas laborales.

Si bien sólo llegaron a ser miembros in pectore de las clases medias funcionales, es interesante que consideremos el caso de los universitarios ubicados ahora al final de su juventud (en general de origen humilde), a los que se les 'prometió' socialmente que las credenciales educativas les garantizaban el acceso a un status socioeconómico medio/alto, y una profesión prestigiosa (es paradigmático el caso de los ingenieros superiores), pero a los que la crisis bloqueó el acceso al mercado laboral. Se identifica con posiciones del eterno "becario" que sufre humillaciones y es explotado, expresando una máxima disonancia entre el desempeño de labores hipercualificadas y condiciones laborales vergonzosas: "te tratan como si fueras 
mierda" (E8). Este colectivo se encuentra en un verdadero estado de shock: la capacidad y el esfuerzo no han servido para nada, pero ya no es posible cambiar de estrategia. Insisten obsesivamente en la vía meritocrática, pero, al mismo tiempo, son los que elaboran una crítica más demoledora acerca de la degradación y corrupción del modelo meritocrático. Identifican una meritocracia infame, falsa y vil que no ha correspondido a sus esfuerzos, sacrificios y a los méritos acumulados: "hemos sacrificado muchas cosas para conseguir esta carrera [ingeniería superior]", "estudiando como un monje desde los dieciocho años" (E8). Las credenciales educativas se degradan en el contexto de la crisis, y no les permiten acceder al mercado de trabajo ni a una vida adulta. Pero, al mismo tiempo, no son capaces de articular estrategias alternativas, y finalmente perseveran en la salida meritocrática, concentrada en "intentar añadir más líneas a mi currículum" (E8). La posición de estos sujetos se ilustra muy bien en la siguiente identificación: "yo soy una hormiguita" (E8), esto es, un trabajador incansable, concienzudo, pero al mismo tiempo $-\mathrm{y}$ sobre todo-, un sujeto condenado a la más absoluta insignificancia en el contexto del hormiguero, y en ese sentido, prescindible.

\section{C) El elitismo meritocrático en las clases medias funcionales empobrecidas}

En las posiciones más extremas, encontramos manifestaciones de un elitismo meritocrático de orientación tecnocrática ${ }^{14}$, que como cabría esperar, se corresponde - en términos generales - con la fracción de las clases medias funcionales que ha gozado de un estatus socioeconómico más elevado (aunque ahora en situación empobrecida). Se trata de una posición relativamente minoritaria en nuestro campo (es el sector más resistente en términos generales a la crisis y a la caída hacia una situación de pobreza), pero, al mismo tiempo, articula un discurso de imprescindible consideración, y extremadamente paradójico en su formulación. Lo realmente interesante de su argumentación es que choca frontalmente con las condiciones sociales y materiales que se atraviesan (desempleo, privación...) y que exige de un notable esfuerzo de racionalización. Es un discurso repleto de eufemismos y de teatralizaciones idealizantes con respecto a sus condiciones vitales.

Este segmento elitista - a pesar de su salida del mercado de trabajo- mantiene unas expectativas elevadas, que discursivamente se convierten casi en certezas. Tiende a relativizar la situación de crisis. El sujeto tiene control de su vida, encontrará lo que busca y lo que se merece. Desde ese punto de vista, el elemento central es la 'voluntad' del sujeto, que se impone sobre las difíciles condiciones del entorno ("estoy viendo también sobre todo a qué me quiero dedicar" GT2). El sujeto conseguirá aquello que se propone, no hay lugar —a nivel discursivo- para la adapta-

${ }^{14}$ Para una caracterización de su base teórica, que arranca de la obra de Weber y Schumpeter, puede consultarse el análisis que hace Held (2001: 181 y ss.), en su capítulo 'El elitismo competitivo y la visión tecnocrática', en el que pone de manifiesto cómo desde esta posición se maneja un concepto muy restrictivo de la democracia (ibid.: 182). 
ción con respecto a la realidad del mercado laboral (sin embargo, a nivel estratégico sí que abordan procesos de reorientación y reconversión profesional, a través de la formación).

Mientras llega 'su momento', el de la reincorporación exitosa al mercado de trabajo - que se acerca inexorablemente- esta fracción de las clases medias funcionales en paro, tratan de mejorar el nivel de sus credenciales educativas, siempre que dispongan de recursos económicos — propios o familiares - , a través de la formación reglada y específica, para de esta manera 'revalorizar' - y diversificar- su capital profesional. Implícitamente contraponen su 'optimización del tiempo' y su actitud activa, con la desidia y apatía que atribuyen a las clases populares. En realidad son conscientes de que su empleabilidad ha descendido, de ahí la importancia de reciclarse, pero desde su óptica de trata de una 'optimización', no una reorientación laboral.

No obstante, el discurso de esta fracción está atravesado por una continua y potentísima racionalización, se está ocultando sistemáticamente la humillación asociada al despido, la frustración de carecer de un puesto de trabajo, y sobre todo, la imposibilidad de encontrarlo (especialmente duro cuando las expectativas son tan elevadas). Su situación vital no es tan relajada como pudiera parecer, también está asociada a privaciones. El malestar se reprime y se controla en la situación grupal. Ellos también se están viendo obligados a acceder al espacio desregulado de la economía sumergida para salir del paso (por ejemplo, impartiendo clases particulares).

Se reclama una meritocracia que ponga fin a las aspiraciones desmedidas de igualdad, cada cual debe ocupar el lugar que le corresponde. No todos podemos ocupar posiciones de elite: "todos queremos ser seleccionadores, todos queremos ser ministros, todos queremos ser consejeros, todos queremos ser asesores, entonces claro, cada uno tiene sus verdaderas limitaciones" (GT2). En ese sentido, la crisis estaría realizando una labor de valor incalculable, tras una década de espejismos, de dinero fácil, de éxitos inmerecidos, está poniendo a cada cual en su lugar, posibilitando el regreso de una 'aristocracia natural'. En ese contexto esperan recuperar la posición entre la elite que les corresponde. Surgirá un nuevo equilibrio, basado en un aumento de la desigualdad social. De esta manera, los elitistas meritocráticos están legitimando, y hasta esperando con ansiedad, esa mayor desigualdad que les reubique en su posición 'natural'. Para este sector, es necesario formar a una elite reducida, limitar el acceso a la educación superior (a las clases populares, que han corrompido todo), y lo que es más relevante, eliminar de raíz los mecanismos dirigidos a garantizar una cierta igualdad de oportunidades.

\subsubsection{La búsqueda activa de recursos}

A continuación revisaremos las estrategias más básicas y generalizadas en la gestión cotidiana de la privación, que asociamos a la búsqueda activa de recursos.

\section{A) El apoyo familiar}

El apoyo familiar es, sin lugar a dudas, la fuente de ayuda más importante para los 'nuevos pobres'. Salvo una minoría con familias que también se ubican en una 
situación de pobreza y privación severa - y también excepcionalmente en aquellas familias atravesadas por conflictos graves - los 'nuevos pobres' logran sobrevivir fundamentalmente gracias a los familiares, y especialmente gracias a la ayuda y cobertura facilitada por los padres/madres ("Yo ahora mismo si no estuvieran mis padres, yo estaría en la calle" GD5). La ayuda familiar no solo es crítica en situaciones de desempleo y/o ausencia de prestaciones, sino que es un complemento esencial para los trabajadores pobres.

Las ayudas familiares son muy efectivas a la hora de normalizar la vida cotidiana porque no sólo implican ayuda material, sino también 'servicios' y apoyo emocional. Es imposible que la ayuda institucionalizada pueda resultar tan versátil, adaptable y cercana. Las ayudas institucionales, por definición, son fragmentarias y mal integradas. Además, el apoyo afectivo que proporciona la familia (...y también en algunos casos los amigos, especialmente entre las mujeres y los jóvenes), tiene un evidente efecto terapéutico. La ayuda familiar conforma una situación de "normalidad subvencionada', que a la postre termina siendo ficticia aunque se logren mantener ciertos estándares de bienestar. La fortaleza de la familia, y los apoyos todavía construidos sobre la noción del deber ${ }^{15}$, están teniendo un efecto cohesionador nada despreciable en el contexto de la crisis.

Aunque en general las ayudas familiares son bien 'aceptadas' y se proyecta sobre ellas un fuerte reconocimiento, la vivencia de la ayuda es ambivalente - entre la fortuna y la carga - en tanto en cuanto, depender de la familia supone un paso atrás en la autonomía, en ocasiones implica una infantilización del sujeto (especialmente entre los jóvenes), y sobre todo, porque se asocia a una situación de fracaso personal. Esa ambivalencia anticipa la posibilidad de una deriva conflictiva. Especialmente entre los varones de clase obrera, la situación de dependencia es vivenciada frecuentemente como una situación humillante, es una circunstancia que "jode" (GD2). Es por ello, que quien no depende de sus familiares lo hace manifiesto ("yo no... gracias a Dios no dependo de mis padres" GD2). En el caso de los varones se hace referencia casi exclusiva al apoyo material recibido de la familia, mientras que las mujeres son mucho más explícitas a la hora de agradecer y señalar la centralidad del apoyo emocional y los servicios recibidos.

El apoyo mayoritariamente fluye desde las generaciones de más edad hacia las más jóvenes (prototípicamente de padres/madres hacia los hijos) lo cual supone una nueva versión (no emulativa, sino de puro y duro subconsumo) del consumo vicario o delegado.

${ }^{15}$ Incluso, en ocasiones y en términos económicos, apoyo recíproco. Entre algunos jóvenes de clase obrera la contribución económica al hogar, aunque testimonial, es vista como una obligación moral. 
B) La movilización del capital social disponible. La ambivalencia con respecto a las redes amicales

Una constante en nuestro material empírico es la centralidad que se atribuye al capital social $^{16}$ disponible — verdadero factor crítico-, a la hora de acceder a oportunidades laborales. La consideración del capital social es ambivalente, ya que prioritariamente se denuncia la centralidad del 'enchufe' como vía preferente de inserción en el mercado laboral español, y al mismo tiempo, se toma conciencia de que los métodos 'impersonales' de búsqueda son prácticamente inútiles especialmente entre las clases populares- en un contexto de grave crisis económica. En casi la totalidad de grupos y entrevistas, se constata que las oportunidades laborales (restringidas en la mayoría de los casos a la economía sumergida) surgen - directa o indirectamente - a partir de amigos, conocidos, esto es, a partir del capital social disponible.

En general, el apoyo de amigos posee un carácter más puntual que el de la familia, y tiene que ver más con lo emocional. Cuando las expectativas de apoyo material son altas, existe un riesgo elevado de que aparezca la frustración y hasta el conflicto (que no encontramos usualmente en el marco del apoyo familiar, mucho más intenso y estable). Por decirlo de otra manera, la familia no suele 'fallar', mientras que en el caso de los amigos es más frecuente que el apoyo 'efectivo' quede por debajo de las expectativas existentes. Entre amigos se tiende a imponer un esquema de ayuda en el que la compensación - que concreta la relación doncontradón - debe ser más inmediata (“...económicamente, hay veces que sí he tenido que tirar de los amigos, después se devuelve corriendo" GD5) y equilibrada que en el caso familiar.

Así, con respecto a los amigos los discursos se tornan muy ambivalentes, pueden ser un elemento de apoyo importante, o pueden abandonarte a tu suerte ("Yo también a veces veo que hay gente que huye, la gente cercana" GD5). Aparece el tópico según el cual es en las situaciones difíciles cuando es posible distinguir a los verdaderos: los amigos que te abandonan "no son amigos" (GD5). Emerge el espacio de la traición, asociada a la frustración de expectativas de ayuda (especialmente desde una perspectiva material, pero también en forma de apoyo emocional).

La red de apoyo directo entre amigos suelen funcionar más en el caso de las mujeres. La socialidad tiene una marca predominantemente femenina, las mujeres tienden a establecer vínculos afectivos más sólidos, con una dimensión más emocional (usualmente con otras mujeres), sobre los que se puede articular mejor el apoyo mutuo. Los varones tienden a esperar de sus amigos un soporte material y económico, mientras que las expectativas de las mujeres se dirigen más hacia el soporte afectivo y ayudas personales (en forma de 'servicios').

${ }^{16}$ Utilizamos aquí la acepción de capital social popularizada por Bourdieu en términos del conseguido a través de la red de relaciones que establece el sujeto en el campo social. 


\section{C) Servicios sociales y organizaciones caritativas}

En términos generales, encontramos en el colectivo de nuevos pobres un desconocimiento asombroso con respecto a los servicios sociales y los recursos a los que se puede acceder a través de ellos (especialmente entre los varones de clase obrera, pero también entre las clases medias empobrecidas). El sector que parece recurrir de manera más sistemática a los servicios sociales son las madres pobres de familias monoparentales, y también los inmigrantes que padecen niveles más elevados de privación material. En cuanto al colectivo que menos accede a los servicios sociales parece ser el integrado por varones de clase obrera, incluso aquellos en situación de pobreza extrema, en parte por puro desconocimiento, pero también por el efecto estigmatizador atribuido. En el caso de la clase media vulnerabilizada, las referencias discursivas a los servicios sociales sólo las encontramos en los casos de privación severa. Para las clases medias y los varones de clase obrera, los derechos sociales parecen alcanzar exclusivamente hasta donde llegan las prestaciones por desempleo y los subsidios, más allá, no hay Estado, y aparece el 'búscarse la vida' ("Si te han, si se te han acabo tus derechos, si has cobrado tu paro y [...] Búscate la vida vamos ¿no?” GT2).

También resulta llamativo que sean excepcionales aquellas posiciones discursivas - correspondiéndose con la fracción crítica progresiva - que exigen que el Estado cubra directamente las necesidades básicas de los sectores sociales más vulnerabilizados (incluyendo, por ejemplo, entre otros servicios, el desarrollo de comedores sociales de titularidad pública). Se afirma que "el Estado tiene una responsabilidad social" (GT1), es decir, el Estado debe garantizar unos mínimos de subsistencia, pero observan que la administración soslaya ese deber, lo delega, lo que - para esta fracción - tiende a transformarle en un Estado insensible y ciego con respecto a los colectivos más necesitados.

En términos generales, no existe una crítica explícita con respecto a que sean entidades caritativas (aunque sus servicios sean financiados - parcial o totalmente - por parte del Estado), las que implementen mayoritariamente estos servicios de atención directa. La lucha contra la pobreza se vincula simbólicamente de manera exclusiva con las ONG, el Estado no aparece ligado a ese espacio en los discursos. Para todo el segmento de nuevos pobres, la última red de protección, la que garantiza que la gente no se 'muera de hambre', se vincula exclusivamente con las entidades del tercer sector, y entre éstas se habla fundamentalmente de Cáritas (y en segundo lugar de la Cruz Roja). Es decir, se naturaliza la ausencia del Estado en estos espacios de 'emergencia social'. La consecuencia directa es la deslegitimación del Estado como proveedor de medios de subsistencia, en favor de las entidades caritativas, cuya labor solo recoge reconocimiento por parte de los sectores empobrecidos. Así pues, en el contexto de la crisis, las entidades caritativas adquieren una mayor visibilidad como instancias concretas de ayuda real (que se oponen simbólicamente a un Estado mal gestionado y atenazado por la corrupción), mejorando sensiblemente su imagen social.

Entre las mujeres pobres encontramos una posición fuertemente ambivalente respecto a los servicios sociales, que bascula, según el caso, entre el reconocimiento 
y la crítica furiosa. Las percepciones críticas ("los asuntos sociales y todo eso es un engaño" GD5), suelen enfatizar la dimensión de control de los servicios sociales que desplazaría completamente la dimensión ayuda. Se señala así la función represiva de los servicios sociales (retirada de tutela de menores, control humillante de la propia vida, etc.).

El colectivo de inmigrantes muestra una menor resistencia a la hora de solicitar los recursos y ayudas vinculados a servicios sociales. No se ven tan afectados por el efecto estigmatizador o vergonzante que la población autóctona asocia al acceso a este tipo de ayuda. Así, la experiencia relacionada con los servicios sociales se relata de manera fluida en el contexto de los grupos y entrevistas. Al no ligarse la obtención de la ayuda a la existencia previa de un derecho, normalmente no aparece una apreciación crítica de los servicios sociales, los inmigrantes simplemente tratan de maximizar los recursos disponibles.

En ocasiones entre los segmentos empobrecidos que no están en una situación de carencia extrema (muchas veces gracias a la ayuda familiar), se proyecta una visión un tanto simplista e idealizada del acceso a los bienes básicos de subsistencia a través de las entidades del tercer sector: "Porque la gente si tiene una necesidad de comer, pues se va a Cáritas y te dan una cesta con productos básicos", "vas a Cáritas y te dan una cesta para comer ¿no?" (GT2). Esta imagen de 'abundancia' y facilidad en el acceso a los bienes de subsistencia básica, contrasta abruptamente con las dificultades cotidianas y las situaciones angustiosas que relatan los sectores con niveles de privación más elevados.

\section{D) La economía sumergida: Las chapuzas}

Ante un mercado de trabajo 'regular' en caída libre, colapsado por los millones de demandantes de empleo (especialmente con respecto a los trabajos no cualificados, que son a los que aspiran buena parte de los 'nuevos pobres'), y acuciados por un nivel de privación creciente, la presión hacia la economía sumergida es fortísima (aunque eso no signifique que sea ni mucho menos fácil encontrar acomodo en ese nicho laboral).

Dado el enorme peso de la economía sumergida en España ${ }^{17}$, no podemos hablar del trabajo realizado de manera irregular como un recurso alternativo que explotan aquellos que se han visto afectados por un proceso de empobrecimiento severo. Como se refleja en nuestro material empírico, en mayor o menor medida buena parte de los 'nuevos pobres', a lo largo de su trayectoria laboral, ha realizado trabajos sin contrato, ha cobrado parte de su salario 'en negro', etcétera. Pero, es evidente que la economía sumergida pasa a configurarse, en el contexto de la crisis, en un mecanismo fundamental para acceder a unos ingresos irregulares - salvo excepcio-

${ }^{17}$ El peso de la economía sumergida en la economía española — según datos del colectivo de Técnicos del Ministerio de Economía y Hacienda (Gestha) — se cifraba en 2008 en un $23 \%$ del Producto Interior Bruto. 
nes-, o para complementar unos exiguos subsidios que no permiten alcanzar el simple nivel de subsistencia. Es de sobra conocido que, si por algo se caracteriza el trabajo en la economía sumergida es por su inestabilidad, precariedad, inseguridad, $\mathrm{y}$ muy frecuentemente, por sus condiciones denigrantes.

En la práctica totalidad de las experiencias relatadas en grupos de discusión y entrevistas, los trabajadores se remiten a trabajos esporádicos, de aparición azarosa (como las 'chapuzas', que realizan algunos de los obreros de la construcción en paro). No obstante, la crisis también afecta a la economía sumergida española. Ésta, que antes funcionaba como un gran colchón económico, que complementaba frecuentemente los ingresos regulares del trabajo, sufre una contracción muy importante (severísima en el caso de la construcción). Esto hace muy difícil encontrar incluso pequeñas chapuzas, a la gente le es más difícil 'buscarse la vida'.

Por otro lado, no hemos de olvidar que la generalización de puestos de trabajo 'con contrato' que condenan a sufrir situaciones de pobreza (discontinuos, a tiempo parcial, con remuneraciones en torno al salario mínimo interprofesional, o muy inferiores en el caso de trabajos a tiempo parcial), hace que el trabajador pobre deba apañárselas a través de complementos laborales que permitan la supervivencia. Así encontramos dramáticas situaciones de pluriempleados pobres ${ }^{18}$. El deterioro de las condiciones en el mercado de trabajo 'regular' se proyecta — agudizándose - sobre las condiciones de trabajo en la economía sumergida; se trata de esferas estrechamente interconectadas entre sí, que en muchas ocasiones comparten espacios y sujetos, que se funden en diversas configuraciones.

\subsubsection{La optimización de los recursos disponibles y la adaptabilidad descenden- te en los patrones de consumo}

La 'optimización' de los recursos no aparece como una opción libre, sino que surge como una imposición en un marco de deterioro de la capacidad adquisitiva, que se traslada y concreta en una situación de privación. Este contexto de privación implica una deriva hacia un consumo dominado por la necesidad y la premisa racional (donde los factores críticos son el valor de uso, y éste siempre supeditado al precio). El valor de uso desplaza totalmente los elementos simbólicos del consumo, y en ese sentido, nos remite al consumidor plenamente racional, al improbable - empíricamente- homo oeconomicus de la teoría neoclásica. Las estrategias de optimización son muy diversas, dependiendo del colectivo, de su situación vital y económica (de su nivel de privación). Es curioso observar cómo las estrategias de

${ }^{18}$ Tal situación la ilustra paradigmáticamente nuestra entrevista E7 realizada a una trabajadora pobre joven, que compagina el trabajo en una fábrica de pulseras (de lunes a viernes), el trabajo en una instalación deportiva un día a la semana, y la venta puntual de objetos de artesanía que elabora ella misma, y que aun así, no logra superar el umbral de la pobreza. (Como nota amarga, tan sólo unos días después de la entrevista, esta joven fue despedida de la fábrica de donde procedía el grueso de sus exiguos ingresos). 
optimización son más variadas y efectivas entre los individuos - de orientación ideológica progresiva - que han ocupado posiciones de clase media funcional ${ }^{19}$.

En este contexto es en el que surgen referencias a los efectos positivos de la crisis. La escasez hace 'agudizar el ingenio', 'sacar de donde no hay', en definitiva, promueve y presiona hacia la maximización y optimización de los recursos disponibles. Cuando se habla de los subsidios y ayudas de en torno a los cuatrocientos euros se dice: "con eso haces maravillas" (E4). Nos encontramos con grandes 'equilibristas' económicos que están continuamente en el alambre. La crisis provoca una completa 'recalibración' del valor del dinero ("valoras mucho más la pasta" GD1), lo cual se vincula necesariamente a una estrategia de contención respecto a las prácticas de consumo.

La optimización de recursos se vincula claramente a una pérdida en el nivel de bienestar, un retroceso que les retrotrae a modelos de consumo prototípicos de otros momentos históricos, que les empuja a vivir como en los duros tiempos de la postguerra española, como señalan los obreros: “...comiendo judías, garbanzos, lo que... lo que se hacía en los tiempos de nuestros padres" (GD2). Se percibe como una degradación de tal calado en el bienestar material que se plantea entre los varones pobres de clase obrera como una vida que se desliza peligrosamente hacia el sinsentido (una vida sin vida). La privación enclaustra en el hogar y hace imposible realizar elecciones vitales básicas: "vivimos en... en... lo que es... eh... la esclavitud pero en libertad" (GD2).

El discurso de 'resignación ascética' sería la posición que mejor representaría la situación de 'adaptabilidad descendente' de los consumos, en un marco de deterioro de la situación económica familiar. En este caso, nos referimos más a una variante discursiva y a una actitud moral, que a una estrategia de acción concreta. Se trata de un discurso que acompaña (en ciertas ocasiones) a la optimización, y que como señalamos, nos remite a un planteamiento más moral (de reminiscencias puritanas y ascéticas) que pragmático (lograr la supervivencia y maximizar el bienestar). Podemos señalar que esta posición discursiva refleja claramente el "efecto disciplinario que la crisis desarrolla - especialmente entre los sectores populares-" (Alonso et al., 2011: 258).

En todo el colectivo de nuevos pobres encontramos procesos de 'adaptación descendente' de los consumos, pero sólo un segmento hace de la justificación de esta estrategia necesaria el elemento central de su discurso sobre la crisis. Esta posición discursiva es muy característica de los sectores de nuevos pobres que no

${ }^{19}$ Participan más en iniciativas de consumo colaborativo, están más abiertos a ensayar nuevas fórmulas (por ejemplo, compartir gastos de viajes a través de páginas web 'especializadas'). También es más frecuente que utilicen la 'bici' para sus desplazamientos urbanos (curiosamente la clase obrera empobrecida no es capaz de plantearse esa solución de movilidad, aun cuando se trate de una alternativa muy viable y accesible por su bajo coste), o se planteen alquilar una habitación para facilitar el pago de la hipoteca, etc. 
padecen una situación de pobreza extrema, y que en ese sentido, todavía son capaces de 'bandearse'. Es especialmente definitorio de una fracción de la clase media baja empobrecida. Además, encontramos una fuerte marca femenina. Dominado por la capacidad - entendida sobre todo como virtud - de adaptarse y conformarse ("me he adaptado a lo que he tenido", "me he conformado" GD3), estamos ante un discurso resignado, que no cuestiona el 'orden social dado' ("te tienes que adaptar a lo que hay" E1), y que se vincula al mismo tiempo a un estado de aparente normalidad (inserto en una lógica de ocultación de la privación, en un difícil 'juego' por mantener las apariencias). Es una posición que se presenta como equilibrada y realista, y que se enuncia esquivando la desesperación y la angustia, aunque en ocasiones tras la fachada de fortaleza se desliza la pesadumbre y el desasosiego asociados a la posibilidad de sufrir más privaciones; la resignación ascética no disuelve la incertidumbre: "lo que agobia es la intranquilidad... la intranquilidad económica que hay, la inseguridad que tengo" (GD3).

El discurso de la resignación ascética, se caracteriza por la "contención y responsabilidad" (Alonso et al., 2011: 258), y se articula como un "discurso moral contra el derroche y contra los excesos" (ibid.: 263). Es un discurso de matiz conservador: en el fondo, se articula en torno al deber de ocupar y adaptarse a la posición social que a cada cual le corresponde, y eso, tiene un claro correlato en los modelos de consumo y los estilos de vida. La crisis pondría en claro y afectaría fundamentalmente a quienes han tenido la osadía de tratar de abandonar su posición social - transgrediendo el orden 'natural'- De ahí el ataque visceral y colérico, y la condena moral, que se dirige a los consumos emulativos.

Desde esta posición discursiva, la crisis proporciona una oportunidad para la moralización, posibilita una verdadera regeneración, que pasa por el abandono radical del consumismo ("Yo en lo general lo puedo ver negro, pero yo creo, pero yo creo que en lo particular nos va a hacer ser mejores personas [...]. Pero es que si somos materialistas, si cambiamos eso y logramos cambiar eso, podría ser muy positivo" GD3). Indirectamente se desliza el poder purificador de la penitencia (asociada a la situación de crisis). La adaptabilidad descendente se articula en torno a una crítica global al consumismo y el hedonismo, y vincula la situación de privación (que ellos no sufrirían en sentido pleno) a la falta de previsión. En ese sentido, este discurso 'puritano', de renuncia ascética y moral, es el máximo exponente del diagnóstico según el cual se ha vivido 'por encima de nuestras posibilidades'.

\subsubsection{Las estrategias extremas de supervivencia multimovilizada: los espacios del 'trapicheo'}

Con la referencia al trapicheo, no sólo nos referimos a los espacios menos formalizados de la economía sumergida (buena parte de los nuevos pobres depende, en menor o mayor medida, del trabajo realizado en contextos no regulares/legales). Se trata de un espacio que va más allá de la chapuza, del trabajo informal, accediendo a espacios 'marginales' con fuerte potencial estigmatizador, que implican frecuentemente buscar recursos al margen de la esfera del trabajo. De hecho podríamos 
señalar que el trapicheo ${ }^{20}$ tiene que ver más con tareas de supervivencia que con el trabajo en sentido estricto (lo cual no significa que no se asocie a la realización de labores exigentes físicamente y con una dedicación temporal prolongada), son estrategias extremas de supervivencia multimovilizada. Se concreta en actividades que acentúan el 'vivir al día', son labores típicas en posiciones marginales tradicionales: recogida de chatarra, cartón, palés de madera, plástico, comida. En ocasiones incluso se deslizan hacia actividades potencialmente delictivas - mayoritariamente hurtos- . La prolongación de la crisis y su dureza hace que la presión sobre estos recursos 'de la calle' haya aumentado muy sensiblemente, produciéndose también aquí una creciente competencia entre pobres.

\subsubsection{Las huidas y los imaginarios escapistas}

Ahora consideraremos el rico universo de las estrategias insertas en una lógica de la huida, que en ocasiones se configuran como posibilidades reales, pero que frecuentemente aparecen más bien como imaginarios escapistas.

\section{A) La fantasía eco autárquica}

Aparece con variantes en la práctica totalidad de nuestros grupos y entrevistas. Es una imagen tremendamente potente (pero que se configura casi siempre más como una referencia 'mítica' que como una posibilidad concreta de supervivencia), que se fortalece al constituirse como opuesto simbólico del mundo urbano, que es el que se desmorona con la crisis, y en el que no encuentran espacio (...trabajo, medios de subsistencia). Se trata más de una huida - retórica - al 'campo' (al entorno natural virgen donde desarrollar modelos de vida autárquicos, donde poder recurriendo al tópico bíblico - ganarse el pan directamente con el sudor de su frente), que un retorno a la comunidad perdida. No se busca un refugio comunitario, el referente es la producción autosuficiente de recursos, y la potenciación de la autonomía desde una perspectiva económica. No obstante, también está implícita la idea del retorno a los orígenes, a lo natural, a lo puro. Es una salida regresiva que se opone simbólicamente al fracaso del 'progreso' que la actual crisis ejemplifica. En ocasiones, no se plantea como una huida en sí, sino como simple consecuencia del proceso de 'caída', una necesidad en un contexto de descenso del nivel de vida un proceso adaptativo impuesto-, en el que es necesario "hacer más las cosas con las manos [ríe], e incluso cultivar tus propios alimentos" (GT2).

Es normalmente a partir del convencimiento de ser un sujeto inempleable en el contexto de la crisis (al toparse o más bien estrellarse contra la dura realidad), cuando surgen las fantasías del autoabastecimiento económico (de la eco autarquía),

${ }^{20}$ En el diccionario de la RAE, las acepciones de trapichear son: 1) comerciar al menudeo, 2) Ingeniarse, buscar trazas, no siempre lícitas para el logro de algún objeto. Ambas acepciones son plenamente aplicables a las actividades a las que queremos referirnos en este epígrafe. 
es decir, de ganarse la vida — conseguir los medios de vida — directamente a partir del propio trabajo y esfuerzo autoadministrado en el medio natural, sin depender de la organización del trabajo existente y la economía formal, y eso es posible fundamentalmente a través de la actividad agrícola y ganadera. Pero es aquí donde los pobres 'urbanitas' despiertan de su sueño, sus capacidades y conocimientos les son inservibles (salvo excepciones) para ese fin, y carecen de los medios materiales para producir ("pero yo no sé hacer nada, me iba a morir de hambre" GD3).

\section{B) La huida 'interior'}

La huida interior toma dos formas, la primera la identificamos con las estrategias de carácter 'autista' que se concretan en el enclaustramiento doméstico, y la segunda toma la forma de una evasión de carácter más activo, que busca implementar a través de la propia actividad una estrategia amnésica, que permita escapar de la consideración del duro contexto vital.

\section{b.1.) Las estrategias 'autistas'. El enclaustramiento doméstico}

Es una estrategia vital que se corresponde con la posición de 'acabamiento' que se concreta especialmente entre los varones de clase obrera (de edades intermedias) con trayectorias de paro de largo recorrido. En realidad es una 'antiestrategia' que tiene que ver más con la denegación de la realidad que con el desarrollo de un plan de acción. Es más, normalmente aparece como consecuencia del fracaso de las estrategias desarrolladas previamente.

Nos encontramos ante una estrategia de huida enormemente destructiva. El 'acabamiento' se concreta en el momento en el que el sujeto toma conciencia de que los esfuerzos para reintegrarse en el mercado de trabajo son absolutamente inútiles, y no vislumbra alternativa alguna. Sienten que han agotado todos los medios a su alcance, y llegan al convencimiento de que hagan lo que hagan resultará imposible encontrar trabajo. Se ven en la posición de Sísifo, condenado por Hades a empujar montaña arriba una enorme piedra que siempre se le escapa de las manos al llegar cerca de la cima. Como en el caso de Sísifo, para los obreros, buscar trabajo se erige en una tarea titánica, sin fin y sin objetivo. Es la ejemplificación máxima de la futilidad del esfuerzo (“...y ya, hagas lo que hagas, te va a dar igual, vas a volver siempre al mismo punto ¿Cuál es el punto? Estás parado. Y te puedes mover por donde tú quie..." GD2).

Para qué volver a intentar subir la piedra si rodará ladera abajo (para qué intentar de nuevo buscar trabajo, si es imposible encontrarlo). Se acepta pues sumisamente un destino visto como ineludible y cruel. Una parte importante de los obreros terminan asumiendo que es totalmente imposible subir la piedra hasta la cima (asumiendo con ello dolor y frustración). La solución que pergeñan estos obreros es tratar de olvidar - inútilmente - que hay una piedra que empujar que jamás llegará a hollar la cima.

La imagen extrema de este acabamiento y enclaustramiento doméstico, la encontramos en la imagen del 'encamado' que aparece reiteradamente en nuestro grupo de obreros pobres, y que se asocia a la desestructuración de los horarios y de la propia cotidianidad ("...no me levanto por la mañana, me levanto al mediodía. 
Porque no me quiero levantar por la mañana, porque si no, me cae el mundo encima, porque me sobran horas por todos los cuatro costados" GD2). La huida les lleva al repliegue absoluto, a esconderse de la mirada de los demás. Literalmente el mundo se les cae encima y viéndose impotentes, superados, se hunden y huyen 'hacia adentro', tratando de escapar de una realidad terca y dura. Íntimamente saben que no es la solución, el hogar no es un espacio cómodo para ellos, pero no son capaces de encontrar alternativas viables.

Entre los obreros observamos pues un repliegue anómico (han perdido la base reguladora fundamental de sus vidas: el trabajo). Estos varones se definen como sujetos activos (incluso 'hiperactivos'), y por ello les abruma la inacción y parálisis a la que les condena la pérdida del trabajo, pero, paradójicamente la fracción dominante desarrolla estrategias que acentúan la inactividad. Desplazados del trabajo, la cotidianidad resulta insoportable, tratan de 'matar el tiempo' ("matar el tiempo en tu casa inconscientemente todo lo que puedas..." GD2), no de activarlo a través de actividades de ocio que generen bienestar y posibiliten la realización personal. El ocio social que antes practicaban está ligado al consumo, y se encuentra ahora fuera de su alcance. Ocupan su cotidianidad con actividades de desconexión, escapistas, amnésicas, que no proporcionan ningún tipo de sentido vital (televisión, videojuegos...), y que a la postre, nada aportan salvo más angustia y malestar (“...me puedo tirar doce horas tirado en el sillón viendo la tele como un gilipollas" GD2). Se sienten atrapados, acabados, son verdaderos muertos (sociales) en vida ("soy medio vegetal, medio humano" GD2). En definitiva, están hundidos y amargados; agonizan en el hogar.

\section{b.2.) No pensar, no sentir dolor: la evasión activa}

Otra estrategia de huida interior (aunque en una variante no destructiva), se orienta a gestionar el presente, a luchar en la cotidianidad ("vive día a día y no pienses ni en el futuro ni en el presente" GD5), 'simplemente' para lograr satisfacer las necesidades básicas, sin realizar un planteamiento reflexivo sobre qué se está haciendo con la vida ("porque te hundes" GD5), sobre cuál es el futuro que les aguarda, sin hacer una valoración global de sus condiciones de existencia (bloqueando de esta manera, en la medida de lo posible, la sensación de fracaso), sin dar sentido ni siquiera al momento presente (más allá del impulso dirigido a la supervivencia). Se trata de una estrategia dirigida 'simplemente' a soslayar la desesperación, a evitar el desplome vital, a minimizar el dolor y la angustia. Esta estrategia no se dirige a la inacción como en el caso anterior - todo lo contrario-, puede estar asociada a una actividad frenética orientada a la supervivencia. "Ya no pienso nada [...] Sino solamente que haya alimentos en casa y, y el resto que vaya sólo. Porque te pones a pensar [...] no lo puedes cambiar, no lo puedes cambiar" (E2). Es una posición muy típica entre las mujeres en familias monoparentales, y algunos segmentos de inmigrantes, en ambos perfiles en situación de privación severa. En estos casos, el sentido vital depende y reside en los hijos. 


\section{C) La emigración: la huida exterior}

En general la propensión a buscar en la emigración la salida a la crisis aumenta cuanto menor es la edad y mayor es el nivel de estudios. Son los titulados universitarios jóvenes los que más seriamente se plantean la salida al extranjero. En gran medida se mira al norte de Europa como posible destino.

La salida al extranjero, aparece como opción mayoritariamente retórica para el conjunto de las clases populares empobrecidas, por ello, discursivamente se plantean disculpas a la hora de concretarla. La edad y las cargas familiares son esgrimidas como los factores que más dificultan dar el salto hacia otros países en busca de trabajo. Así, entre ciertos sectores de los adultos se afirma: "si realmente eres aventurero lo haces a los veinte algo, pero no a los cuarenta y algo, porque yo creo que más o menos, todas las cosas tienen su momento..." (GT2). También se hace referencia a los hijos como coartada "si yo no tuviese niños, yo me iba del país fuera [...] nosotros lo hemos pensado" (E1). Entre los jóvenes la dinámica es similar, aunque los argumentos que articulan como justificación a un deseo (emigrar) que no pueden satisfacer, están más vinculados a lo económico: se irían pero bajo ciertas circunstancias mínimamente favorables: "yo si me voy, lo que tú dices, con un contrato, es decir, que tengo un trabajo y seguro", "yo si me voy de aquí, hombre, yo quiero llevarme algo, es decir, pa que no me pille", "a mí también me gustaría ver Madrileños por el mundo sin dinero" (GD6). Podríamos decir - a pesar de un pasado de emigración - todavía persiste un temor difuso entre los españoles a salir fuera, que es especialmente intenso en las clases trabajadoras.

\section{D) El retorno a los origenes: el caso de los inmigrantes}

El retorno es muy duro cuando no es elegido en función del logro de objetivos, dado que supone la aceptación de un fracaso. Hay que darse cuenta que la mayoría de los inmigrantes plantean su estancia en España como temporal, como una vía para acceder a recursos económicos que les permitan una vida mejor - esto es, una vía de movilidad social ascendente- en su país de origen (acceder a una casa en propiedad, establecer un negocio...). Además, plantearse el retorno, forzado desde una posición económica desfavorable, implica volver a comenzar de nuevo en lugares donde ganarse la vida es también difícil ("volver a empezar otra vez de cero o por debajo de cero, muy mal" E2). Por otro lado, no se regresa a la situación originaria, se ha perdido gran parte del capital social básico para desenvolverse, se han perdido claves interpretativas, la vuelta se produciría sin capital económico. Se trata de un panorama muy duro. Muchas veces también tienen hijos nacidos y/o criados en España que les atan con la sociedad de destino. No obstante, especialmente en el sector de emigrantes 'supervivientes' (adaptados a la subsistencia en circunstancias de 'marginalidad'), no asusta el ganarse de nuevo la vida en el país de origen ("la vida me la puedo a ganar tanto sea aquí [en España] o ahí [en Marruecos]" E2).

La vuelta supone además enfrentarse a un nuevo choque con la cultura de origen ("mentalmente me va a costar mucho" E2). Se señala el proceso de cambio asociado a su vida en España: "te has adaptado a otra vida, a otros sistemas, a otros... 
vuelves a Marruecos y tienes que volver a otros años, mentalmente, o lo que sea... la forma de vivir, de actuar con la gente, y convivir con la gente" (E2). Volver a ese 'pasado' que se ha dejado atrás, implica admitir un periodo malgastado y desperdiciado vitalmente, en definitiva, reconocer un fracaso.

\section{E) Las expectativas no racionales: La esperanza y la fe}

Se trata de otras estrategias de búsqueda de sentido que escapan del análisis racional del contexto vital. La esperanza ${ }^{21}$ no se articula como una expectativa real/sólida, que surge de la consideración concreta de una situación dada. Podríamos apuntar que, en sentido estricto, no es una estrategia de huida, sino que implica la instalación del sujeto en el orden del deseo. La esperanza - como estado de ánimo positivo - no parte necesariamente de criterios de valoración racional (normalmente se trata de todo lo contrario, por ejemplo, concretado en afirmaciones del tipo 'tengo una corazonada'). De hecho, el 'recurso' a la esperanza aparece cuando las expectativas racionales se disuelven en la cotidianidad. La articulación de la esperanza puede ser perfectamente 'irracional', es más, en ocasiones se confronta a una terca realidad que se impone (por ejemplo, en un contexto de crisis). Así, la esperanza aparece como la última posibilidad — que puede ser remota, desde una perspectiva 'objetiva'-, y en ese sentido, es en el que se utiliza la expresión "La esperanza es lo último que se pierde" (GT2). Asimismo, el universo simbólico de la esperanza se abre hacia la posibilidad de restitución de 'lo justo', de lo merecido, y por supuesto, también se ha remitido tradicionalmente a la esfera de lo religioso, a la intercesión divina, a la esperanza de salvación, y más indirectamente al 'milagro'. Por otro lado, la esperanza denota una actitud pasiva, que se opone a las estrategias activas (ya agotadas como posibilidad).

La esperanza también implica un intento de sobreponerse anímicamente a la adversidad (a veces conlleva la negación de la realidad para seguir hacia adelante), contribuye a hacer soportable la realidad en situaciones extremas. Es decir, instalarse en la esperanza supone desarrollar una estrategia que trata de evitar caer en la 'desesperación'. En cierta medida la esperanza supone 'puentear' la consideración racional de una situación que conduciría a la angustia. La posición discursiva de la esperanza se ubicaría, en cierto sentido, en el universo de la autoayuda, de la necesidad de ser positivo, de crecerse ante la adversidad, de perseverar, de no darse por vencido ("...tenemos que intentar ser... dentro de lo malo, ser positivos y ver que esto no va a durar... [...] no va a durar siempre" GD3). Entre los nuevos pobres son las mujeres las que se instalan de manera más clara en la esperanza (...de un cambio 'azaroso' del destino que cuestione lo racional), los hombres se ubican más en las expectativas racionales. Las mujeres en general se muestran más positivas, más esperanzadas. No obstante, aunque parezca paradójico, las mujeres afectadas por la

${ }^{21}$ Con respecto a la esperanza, la definición del diccionario de la RAE supone una buena orientación: "Estado del ánimo en el cual se nos presenta como posible lo que deseamos". 
crisis, en el día a día, se someten al 'principio de realidad', tratan de apañárselas para salir adelante, muy volcadas en la gestión de las necesidades, en el mantenimiento funcional del hogar, y sobre todo, en la crianza de los hijos.

En el mismo espacio discursivo, también aparece la religión como refugio. Lo encontramos en un pequeño sector de las mujeres, y también entre algún sector inmigrante (fundamentalmente marroquíes y latinos). La crisis favorece neo conversiones religiosas ("yo nunca había sido creyente" GD5), o la 'recuperación' de creencias perdidas o relegadas vitalmente. La evasión hacia lo religioso es mucho más frecuente entre las mujeres, cuando el resto de recursos falla. Surge en contextos de impotencia, cuando simplemente no hay soluciones disponibles en el espacio de lo real - en un momento en el que ya no queda ni un hilo de esperanza-. Literalmente se trata de la búsqueda de un milagro derivado de la intercesión divina, justo cuando no hay nada - ni nadie - en lo que poder confiar en el espacio de lo cotidiano (instituciones, personas...). Las mujeres con cargas familiares 'acuden' a la religión en situaciones desesperadas ("me tuve que agarrar a algo y me agarré. Y yo no sé si será, yo nunca he creído en nada ¿eh? O sea yo nada, y mira ahora llevo mi pulsera, rezo por las noches con mi hijo, pedimos por la niña, no sé, a lo mejor será una necesidad de agarrarte a algo" GD5). La fe aparece como una "herramienta' de gestión de la angustia, en contextos sin aparente solución, en los que las alternativas de acción individual están totalmente agotadas.

\subsection{Las estrategias colectivas}

Pasaremos ahora a revisar las estrategias de tipo colectivo, cuya presencia es relativamente secundaria en nuestro material empírico.

\subsubsection{El refugio grupalista: El comunitarismo regresivo}

En nuestro material empírico se explicitan dos 'variantes' de este comunitarismo que podríamos denominar regresivo (que se agota en la búsqueda de la grupalidad afectiva), y en ambos casos se desarrolla en el entorno de poblaciones relativamente pequeñas, en las que se mantiene un cierto comunitarismo 'tradicional'. Es el caso de entornos con fuerte identidad rural ${ }^{22}$, o pueblos relativamente pequeños en la Comunidad de Madrid, en los que los estilos de vida urbanos no se desarrollan totalmente, y por tanto, que no han desplazado completamente los modelos de interacción comunitaria tradicional. La segunda variante podría desarrollarse en ciertos entornos juveniles de barrios obreros.

${ }^{22}$ En nuestra entrevista E4, participa un varón que reside a caballo entre un pequeño pueblo de la sierra de Gredos (su lugar de nacimiento) y Madrid capital, que literalmente huye a su pueblo para escapar de una cotidianidad agobiante y opresiva. Él encuentra refugio y sentido en la pequeña comunidad rural y en una cotidianidad ligada al trabajo manual. 
En este caso, el objetivo se limita a la convivencia grupal, se busca la gratificación directa derivada del 'estar con los otros' y compartir. La inserción grupal pasa a configurarse como un elemento básico de la identidad. Se trata de configurar un espacio de ocio y al mismo tiempo terapéutico, se busca la satisfacción emocional, pero al mismo tiempo también 'matar el tiempo' en un contexto de paro forzoso. La grupalidad se erige como un oasis cálido en medio de la crudeza de la crisis.

\subsubsection{La movilización colectiva}

El contexto de la movilización entre los segmentos sociales empobrecidos es difícilmente caracterizable, no obstante, sí podemos señalar que sólo una fracción extremadamente minoritaria se ha adscrito a movilizaciones colectivas, o es potencialmente movilizable. De hecho, las propias clases populares empobrecidas ven muy improbable su movilización como colectivo, lo que aparece la mayoría de las veces como un deseo difuso, y no como un horizonte próximo de acción política compartida.

La percepción de la movilización es muy diversa, en el colectivo de nuevos pobres parece existir un mayor apoyo, comprensión y afinidad cuanto más bajo es el estatus socioeconómico (aunque la minoría movilizada tiende a corresponderse más con posiciones 'originarias' de clase media). La clase obrera apoya mayoritariamente las movilizaciones del 15-M, e incluso aparece una cierta idealización en los primeros compases del movimiento. En nuestro material empírico llama poderosamente la atención que el sector joven de las clases populares empobrecidas, parecía estar desconectado y ser totalmente ajeno — en la primavera del 2011 — con respecto a lo que sucedía en las calles. Resulta cuando menos sorprendente, casi inaudito $-\mathrm{y}$ al mismo tiempo extremadamente revelador-, que no aparecieran referencias espontáneas al 15-M en nuestros grupos de jóvenes, justo en el momento de mayor efervescencia y repercusión mediática del movimiento. Sin embargo, sí existen valoraciones directas - no forzadas - , en todos los grupos de adultos.

Tanto la clase media baja como la clase media funcional en situación de pobreza se posicionan frontalmente - salvo fracciones minoritarias, incluidos claro está los propios microsegmentos movilizados - en contra de la participación movilizada, en ocasiones, con posiciones extremadamente beligerantes y viscerales. Proceden a identificar a los movilizados como maleantes, hippies, 'perroflautas', vándalos, vagos, etcétera. Existe una distorsión y trivialización del 15-M asociándolo a comportamientos de incivismo extremo, y desde ahí, se deslegitima cualquier propuesta. Se niega cualquier dimensión democrática en la movilización. Para la fracción hegemónica de las clases medias funcionales empobrecidas, la única 'movilización' legítima debe producirse a través del ejercicio del derecho a voto: "No, no; manifestarnos pero a través del voto, o sea a través del voto en las urnas, o sea, votar de una forma coherente" (GT2), "si quieres cambiar un sistema político, en las urnas, ahí es donde..." (GD3). Se trata de una posición 'coherente' claro está, con el mantenimiento del orden establecido.

En nuestro material empírico se reflejan dos variantes principales de movilización que pasamos a caracterizar brevemente a continuación. 


\section{A) El imaginario de la 'revuelta': La movilización defensiva violenta}

Se trata fundamentalmente de un imaginario sin correlato en el espacio de la movilización - al menos por el momento - en España. La posición de referencia es 'la rabia', que se asocia a una salida violenta y destructiva, en la mayoría de los casos sin trasfondo propositivo (presente incluso en el sector movilizado): "tenemos que estar fuertes y tenemos que empezar a pegar patadas fuertemente" (GT1). El imaginario de la revuelta toma la forma de una venganza contra el poder político, conducida por los sectores populares. Frecuentemente la salida apoyada en la rabia se emparenta con posibles salidas populistas, al demandar un liderazgo carismático que pueda canalizar esa ira y malestar, aglutinar la masa popular contra el poder existente (posición arquetípicamente expresada en nuestro grupo de obreros de la construcción en paro GD2).

A pesar de esa dimensión potencialmente violenta, que puede derivar hacia el simple 'disturbio', la rabia puede aparecer también como precursora potencial de la movilización, el horizonte puede desplazarse de la simple destrucción, del marco de la venganza, y canalizarse hacia la acción política propositiva, que reclame por ejemplo, una articulación más democrática (posición que encontraríamos en nuestro grupo triangular de jóvenes adultos movilizados, GT1).

La explosión de rabia, se contrapone simbólicamente al 'acabamiento', y resulta llamativo que sean precisamente los obreros de la construcción, aquellos que representan más fielmente el perfil de sujeto acabado, los que enuncien con más claridad - y virulencia - la imagen de la movilización destructiva (que curiosamente no aparece en los grupos de jóvenes de clases populares). En este colectivo la revuelta se articula como un escenario imaginario - que es muy improbable que concrete-, un contrapunto evasivo de un colectivo que se sabe totalmente apático y desmovilizado. Es una expresión de 'deseabilidad' (de una movilización colectiva generalizada) que se refleja arquetípicamente en los obreros adultos en paro, pero que también encontramos en otros segmentos movilizados de las clases populares (que en este caso desean que la movilización no sea minoritaria).

Como contrapunto complementario de la búsqueda de un líder mesiánico que encauce a la masa contra el Estado, y acabe con el poder establecido, aparece el discurso elitista meritocrático, que coincide en la necesidad de un liderazgo carismático fuerte, alguien con un 'don' (“...yo creo que falta, yo creo que un liderazgo, para la gente, que sea capaz de llegar a los... a los demás, gente con empatía, gente con... con carisma, imagen, que, que sea capaz de... de transmitir" GT2). La diferencia es que mientras que los obreros pobres piden una movilización contra el Estado (llena de ira), los elitistas meritocráticos de las clases funcionales en paro, buscan en el líder carismático alguien que encauce y dirija 'por el buen camino' normalizado, dentro del orden - a la masa a la que en cierta medida desprecian. Ambas posiciones marcan la existencia de un evidente potencial de deslizamiento hacia la legitimación de posiciones autoritarias, cuando el malestar de las capas populares crece rápidamente. 
B) La protesta política y la movilización propositiva: los movimientos sociales

Encontramos dos posiciones entre los movilizados, una primera fracción adopta un planteamiento 'pesimista' (que parece ser la dominante) con respecto a la potencialidad de movilización y una segunda posición 'optimista' que observa dinámicas positivas.

b1) La posición 'pesimista' decepcionada

Tras casi un año y medio desde el surgimiento del movimiento del 15-M, se deja traslucir en este segmento movilizado una visión decepcionada del nivel de movilización ciudadana en Madrid ${ }^{23}$. Hay un cierto desengaño con respecto a las expectativas levantadas por la movilización. Podríamos hablar de un contexto de cierta 'resaca' y de un descenso de la ilusión. Existe movilización, pero el contexto no es ilusionante, todo lo contrario.

Se considera que la respuesta ciudadana es fragmentaria, con diversos colectivos que hacen la lucha 'por su cuenta', no generándose un bloque social amplio (mayoritario), que es lo que pareció que podía lograrse en los primeros momentos del movimiento $15-\mathrm{M}$. La energía 'popular' parece haberse agotado “....nos tienen divididos y entumecidos. El año pasado [2011] había cierta expectativa de parar estos recortes en educación..." (GT1). Se identifica una fase depresiva - pese a las movilizaciones sectoriales -; el debilitamiento del movimiento a favor de la escuela pública se señala como referencia. La movilización se desliza hacia el 'fracaso' (esta posición es asumida especialmente por el sector movilizado más moderado, con un perfil ideológico más desdibujado). El relato de la movilización, pasa a ser para estos moderados un relato de un fracaso: "no ha servido para nada hacer huelga" (GT1).

\section{b2) La posición 'optimista' adaptativa}

Desde esta posición tampoco se identifican niveles elevados de participación. El movimiento ciudadano no es todo lo vigoroso ni numeroso que debía ser, pero se enfrenta a la estrategia de confusión, distorsión y represión por parte del Estado. El sentido de la movilización es incuestionable: "hay que actuar, uno no hace nada, ni dos, pero uno y otro y otro y otro al final..." (E4). A pesar de reconocer que no se han conseguido avances significativos, hay una percepción más positiva que entre el segmento pesimista. Si se hace una lectura de largo recorrido, la realidad de la movilización ha mejorado significativamente (“...sí que me siento más optimista, o sea, yo sí que veo más, más movilización que hace unos años" GT1), y se piensa que el recrudecimiento de la crisis (y la desesperación y malestar asociado) es fuente de mayor movilización y no de apatía (a diferencia de lo que opinaban los 'pesimistas'): “. . hay gente que ya, como que no tiene nada que perder ¿no? porque como que ya lo han perdido todo, entonces, yo creo que... que esa gente lo único

${ }^{23}$ El grupo triangular se celebró tras el 25-S 'Rodea el Congreso' y sus posteriores 'réplicas' de intensidad descendente, muy condicionadas por la estrategia de contundencia represiva desarrollada por parte de la policía. 
que le queda es buscar alternativas mejores" (GT1). La degradación de las condiciones sociales forzaría la creatividad, la construcción de alternativas.

Por otro lado, la fracción optimista no sólo está considerando la lucha en la calle, sino también la exploración de nuevas alternativas - y redes de apoyo mutuo- a través de lo colectivo, articulando proyectos para transitar otras trayectorias vitales y políticas.

Así pues, entre los nuevos pobres encontramos un segmento marginal de movilizados 'resistentes' — que usualmente partían de una posición de clase media—, que trata de gestionar y minimizar el desgaste, conscientes de que se trata de una carrera de largo recorrido y sin garantías (creen poco probable un cambio significativo), pero al mismo tiempo encuentran su sentido en la propia movilización y la lucha. La futilidad no niega el sentido de la movilización, hay que seguir adelante. Por otro lado, si bien los objetivos políticos pueden no conseguirse, la movilización siempre tiene un efecto social positivo: "las movilizaciones y la organización consiguen por lo menos la concienciación de la gente y que haya redes entre la gente" (GT1). Es muy difícil mantener un nivel elevado de movilización continuamente (las elites juegan con esa ventaja), y las estrategias de represión de la movilización ${ }^{24}$, han generado miedo ("hay mucho miedo" E6). El deslizamiento hacia la represión escenificado en el 25-S, hace que aumente la crítica hacia la democracia formal ("no puedes ni protestar ¿para qué queremos la democracia entonces?” E4).

En un momento en el que la transformación a nivel macro parece complicada, en un contexto adverso identificado como represivo con respecto a las iniciativas de participación y movilización, las propuestas de cambio se articulan en torno a 'proyectos'. Éstos implican la configuración de pequeños reductos comunitarios politizados — de orientación no explícitamente universalista-, que expresan más bien una disposición hacia el apoyo mutuo entre los sujetos movilizados, tratando de generar recursos colectivos. Esto no significa que sean iniciativas cerradas, en general, aspiran a una proyección externa. Se trata de espacios de participación que tratan de escapar a la lógica del mercado.

Podríamos deslindar dos modelos de movilización, que se corresponderían en términos generales con la fracción optimista y pesimista de los movilizados que acabamos de caracterizar. Un primer modelo de movilización parte de la articulación de un sujeto colectivo, que defiende derechos colectivos. El objetivo pasa —en formulaciones muy defensivas, en un contexto de recortes- por "defender el bien común" (GT1), o en otra formulación más vinculada a la consideración de los derechos: "no solamente son tus derechos, estás luchando por los derechos de todo el mundo" (E6). Desde esta posición se articula una crítica del proceso de individualización social, de la "cultura de la individualidad" (GT1), que implicaría una fragmentación de la problemática social.

${ }^{24}$ Represión disciplinaria que también alcanza el ámbito del trabajo "si protestas vas a la calle", "no puedes hacer nada, si tienes un trabajo, estar calladito, aguantar" (E8). 
Si bien la movilización parte mayoritariamente de la defensa de intereses colectivos (dando lugar a una lucha en pos de derechos), en un modelo en el que la acción individual se supedita a lo grupal y colectivo, encontramos un segundo modelo de movilización que deriva de la convergencia —o agregación - de intereses individuales (al constatar que 'mi caso es equiparable al de otros muchos individuos' $)^{25}$. Evidentemente puede producirse una transición desde este modelo de movilización a la modalidad plenamente colectiva (que suele resultar más 'potente'), pero tiene sentido mantener esta distinción, dado que discursivamente se evidencian diferencias significativas. Este segundo modelo de movilización suele tener una base más pragmática, se vincula a la consecución de objetivos concretos frecuentemente de carácter instrumental-, cuya consecución supondría un beneficio directo para el sujeto movilizado. Suele derivarse de un desencanto con respecto al sistema meritocrático formal.

\section{A modo de conclusión}

A lo largo del artículo se han revisado - de una manera muy esquemáticaalgunas de las posiciones discursivas más representativas entre los 'nuevos pobres', atendiendo especialmente a la atribución de responsabilidades con respecto a la crisis, y también se han explorado algunas de las estrategias más relevantes a la hora de encarar las situaciones de privación y desarticulación identitaria que afectan - en muchos casos de forma dramática - a este colectivo. Sin pretender realizar una reducción simplista de la argumentación analítica manejada en el texto, ni una simplificación de la riqueza y complejidad de los argumentos discursivos y las 'tácticas' vitales que se asocian al espacio social —enormemente heterogéneo- de la 'nueva pobreza', sí quisiéramos destacar un elemento especialmente revelador (al tiempo que evidente), nos referimos al hecho de que tanto en las explicaciones sobre la crisis, como en las estrategias desarrolladas para encararla, el sujeto ocupa una posición significativamente central. En los discursos, al sujeto social individualmente considerado, se le atribuye una cuota importante de responsabilidad en la génesis de la crisis - encontramos una autoculpabilización reflexiva que alcanza de lleno a los propios 'nuevos pobres'-, sin que ello signifique en ningún caso que no se apunten otros grandes 'culpables', entre otros la casta política, vilipendiada sin compasión. Por otro lado, a la hora de encarar las consecuencias de la crisis, los 'nuevos pobres' tienden a desarrollar de manera hegemónica estrategias individuales, ocupando una posición relativamente marginal aquellos recursos articulados de forma grupal y/o comunitaria, o incluso institucionalmente (excepción hecha del

${ }^{25}$ El enfoque pragmático hace que prime el objetivo personal. Por poner un ejemplo, defiendo más mi puesto de trabajo como interino en el colegio ' $x$ ', que la escuela pública en su conjunto, a partir de una posición ideológica. 
apoyo familiar, aunque frecuentemente también éste responda a una lógica también individualizada). Además, las estrategias políticas de gestión de la crisis ocupan una posición enormemente residual en un contexto en el que la subsistencia cotidiana, marca despiadadamente la agenda. En ese sentido, la marginalidad de las estrategias políticas y la ausencia de movilización, no son realmente sorprendentes, pero de nuevo, el hecho resulta enormemente significativo.

La consecuencia de este deslizamiento individualizador (que no sólo afecta al colectivo de 'nuevos pobres'), implica que el potencial deslegitimador efectivo del orden institucional - político y económico-, aun en un contexto de verdadera emergencia social, con unos niveles de pobreza y privación inauditos e intolerables, se ubica en unos niveles realmente bajos —al menos por el momento-. Así pues, parece que los potentes discursos centrados en la individualización, y más específicamente en la psicologización de la realidad y vivencia de la crisis (que identifican un individuo enfermizo, superado y abatido, y no un orden social mórbido e injusto), están logrando establecer un marco poco halagüeño para la repolitización colectiva de los 'nuevos pobres'.

\section{Bibliografía}

Alonso, L.E., C. Fernández y R. Ibáñez (2011). "Del consumismo a la culpabilidad: en torno a los efectos disciplinarios de la crisis económica", en Política y Sociedad, vol. $8, \mathrm{n}^{\mathrm{o}} 2,353-379$.

Altheide, D.L. (2001). Creating fear. News and the construction of crisis, New York: Aldine de Gruyter.

Augé, M. (2012). Futuro. Buenos Aires: Adriana Hidalgo.

Bauman, Z. (2011). Daños colaterales. Desigualdades sociales en la era global. Madrid: Fondo de Cultura Ecómica.

Beck, U. (2001). La Sociedad del Riesgo: Hacia una Nueva Modernidad. Barcelona: Paidós.

Berardi, F. (2012). The uprising. On poetry and finance, Los Angeles: Semiotext(e).

Berman, M. (2004) [1982]. Todo lo sólido se desvanece en el aire. La experiencia de la modernidad, México: Siglo XXI.

Cadahia, L. (2012). "El dispositivo de la crisis como nuevo Orden Mundial", en L. Cadahia y G. Velasco (comps.), Normalidad de la crisis/crisis de la normalidad, Madrid, Katz Editores. 
Cadahia, L., Velasco, G. (comps.) (2012). Normalidad de la crisis/crisis de la normalidad, Madrid, Katz Editores.

Camilleri, J.A. (1976). Civilization in Crisis. Human prospects in a changing world. Cambridge: Cambridge University Press.

Carrasco-Conde, A. (2012). "Blow up. Evento, acontecimiento, crisis", en L. Cadahia y G. Velasco (comps.), Normalidad de la crisis/crisis de la normalidad. Madrid: Katz Editores.

Clarke, S. (1994). Marx's Theory of Crisis. New York: Scholarly and Reference Division, St. Martin's Press.

Cockcroft, L. (2012). Global corruption. Money, power and ethics in the modern World, London, IB Tauris \& Co.

Colectivo Ioé (2007). Interpretaciones de la condición migrante. Exploración de los discursos de la población inmigrada en España.

http://www.colectivoioe.org/index.php/publicaciones_investigaciones/show/id/68 (Consultado en noviembre de 2012).

Colectivo Ioé (2011). "Efectos sociales de la crisis. Una evaluación a partir del barómetro social de España, en Papeles de relaciones ecosociales y cambio global, núm. 113, pp. 177-188.

http://www.colectivoioe.org/index.php/publicaciones_articulos/show/id/118 (Consultado en noviembre de 2012).

Colectivo Ioé (2012a). Impactos de la crisis sobre la población inmigrante. Organización Internacional para las Migraciones

http://www.colectivoioe.org/index.php/publicaciones_libros/show/id/101 (consultado en noviembre de 2012).

Colectivo Ioé (2012b). "Crece al desigualdad en España", en Barómetro social de España.

http://www.fuhem.es/media/ecosocial/File/Analisis/2012/BSE2010-

Desigualdad.pdf

Colectivo Ioé, Ortí, A. (2007). La convivencia en Madrid. Discursos ante el modelo de desarrollo de la ciudad y la instalación de población inmigrante. Madrid: Ayuntamiento de Madrid

http://www.colectivoioe.org/index.php/publicaciones_libros/show/id/83

Dominguez Sánchez-Pinilla, M. (2000). "Distintos significados de la crisis", en Nómadas. Revista crítica de ciencias sociales y jurídicas, núm. 1. 
Gómez Ramos, A. (2012). "La inmediatez de la crisis y la experiencia del tiempo", en L. Cadahia y G. Velasco (comps.), Normalidad de la crisis/crisis de la normalidad. Madrid: Katz Editores.

Gómez Serrano, J.P. (ed.) (2011). Economía política de la Crisis. Madrid: Universidad Complutense.

Guerra, A., Tezanos, J.F. (eds.) (2012). Alternativas económicas y sociales frente a la crisis. Madrid: Sistema.

Habermas, J. (1995) [1973]. Problemas de legitimación en el capitalismo tardío. Buenos Aires: Amorrortu.

Held, D. (2001). Modelos de democracia. Madrid: Alianza.

Koselleck, R. (2007) [1959]. Crítica y crisis. Un estudio de la patogénesis del mundo burgués. Madrid, Trotta.

Lakoff, G. Johnson, M. (2004) [1980]. Metáforas de la vida cotidiana. Madrid: Cátedra.

Lanceros, P. (2012). "Tras la modernidad. De la crisis a la intemperie", en L. Cadahia y G. Velasco (comps.), Normalidad de la crisis/crisis de la normalidad. Madrid: Katz Editores.

Laparra, M., Pérez Eransus, B. (coord.) (2012). Crisis y fractura social en Europa. Causas y efectos en España. Barcelona: La Caixa.

Laparra, M., Pérez Eransus, B. (2010). El primer impacto de la crisis en la cohesión social en España. Madrid: Fundación FOESSA.

Lizcano, E. (2006). Metáforas que nos piensan. Sobre ciencia, democracia y otras poderosas ficciones, Madrid: Bajo Cero / Traficantes de Sueños.

Lizcano, E. (2008). "Narraciones de la crisis: viejos fetiches con caras nuevas, en Archipiélago: Cuadernos de crítica de la cultura, núm. 83-84, pp. 33-43.

Lizcano, E. (2012). "Investigando cómo se construye/analiza un imaginario: retórica e ideología en los discursos expertos sobre la crisis económica", en Daniel Ginea-Martín (coord.), Trucos del oficio de investigador. Casos prácticos de investigación social. Barcelona: Gedisa. 
López Jiménez, J.J., Renes, V. (2011). "Los efectos de la crisis en los hogares: nivel de integración y exclusión social", en Papeles de relaciones eco-sociales y cambio social. núm. 113, pp. 189-199.

Lucas, A. de, Ortí, A. (2004). En los límites del desarrollo capitalista: multifrenia consumista y crisis de civilización en el modelo de globalización financiera. Ponencia presentada en el VIII Congreso Español de Sociología, Alicante.

Lukács, G. (1968). Goethe y su época. Barcelona: Grijalbo.

Merton, R.K. (1995) [1949]. Teoría y estructura sociales. México: Fondo de Cultura Económica.

Morin, E. (1995). "Por una teoría de la crisis", en Sociología. Madrid: Tecnos.

Morin, E. (2011). La vía para el futuro de la humanidad. Barcelona: Paidós.

Navarro, V. (dir.) (2012). El impacto de la crisis en las familias y en la infancia. Barcelona: Ariel.

Nieto, A. (2008). El desgobierno de lo público. Barcelona: Ariel.

Observatorio Metropolitano (2011). La crisis que viene. Algunas notas para afrontar esta década, Madrid: Traficantes de sueños.

Orellano, V., Marra, L., Berenguer, L., Collado, A. (2007). Entre piquetes y cacerolas. Huellas de la crisis en discursos sociales. San Juan: EFFA.

Ríos, I. de los (2012). "Mórbida crisis, débil gobierno: Aristóteles y la estrategia del náufrago", en L. Cadahia y G. Velasco (comps.), Normalidad de la crisis/crisis de la normalidad. Madrid, Katz Editores.

Rocco, V. (2012). "El Estado crítico", en L. Cadahia y G. Velasco (comps.), Normalidad de la crisis/crisis de la normalidad. Madrid: Katz Editores.

Salido Cortés, O. (2012). Los ciudadanos españoles ante la crisis. Madrid: Fundación Alternativas.

Sánchez Usanos, D. (2012). "Modernidad, crisis y filosofía", en L. Cadahia y G. Velasco (comps.), Normalidad de la crisis/crisis de la normalidad. Madrid: Katz Editores.

Sennett, R. (2001) [1974]. El declive del Hombre Público. Barcelona: Península. 
Stiglitz, J.E. (2012). El precio de la desigualdad. El 1\% de la población tiene lo que el 99\% necesita. Madrid: Taurus.

Surya, M. (2012). De la dominación. El capital, la transparencia y la corrupción. Madrid: Arena Libros.

Tezanos, J.F. (ed.) (2012). Los nuevos problemas sociales. Madrid: Sistema

Velasco, G. (2012). "Crisis de la construcción social de la normalidad capitalista", en L. Cadahia y G. Velasco (comps.), Normalidad de la crisis/crisis de la normalidad. Madrid: Katz Editores.

Wallerstein, I. (1984). El moderno sistema mundial II. El mercantilismo y la consolidación de la economía-mundo europea, 1600-1750. Madrid: Siglo XXI.

Žižek, S. (2009). Primero como tragedia, después como farsa. Madrid: Akal. 